\title{
ONE PERSON, ONE VOTE REVISITED: THE IMPENDING NEGESSITY OF JUDICIAL INTERVENTION IN THE REALM OF VOTER REGISTRATION
}

\section{MaRK ThOMas QuINLIVAN $\dagger$}

No right is more precious in a free country than that of having a voice in the election of those who make the laws under which, as good citizens, we must live. Other rights, even the most basic, are illusory if the right to vote is undermined.

- Wesberry v. Sanders, 376 U.S. 1, 17 (1964)

As long as ours is a representative form of government, and our legislatures are those instruments of government elected directly by and directly representative of the people, the right to elect legislators in a free and unimpaired fashion is $a$ bedrock of our political system.

- Reynolds v. Sims, 377 U.S. 533, 562 (1964)

Twenty-five years ago, the United States Supreme Court intervened in the electoral realm and mandated the rule of "one person, one vote" in congressional ${ }^{1}$ and state legislative ${ }^{2}$ districting. ${ }^{3}$ After having found the redistricting question to be justiciable in Baker v. $\mathrm{Carr}^{4}$ and faced with gross malapportionment and legislative resistance to reform, ${ }^{\mathrm{B}}$

† B.S.F.S. 1987, Georgetown University; J.D. Candidate 1990, University of Pennsylvania.

1 See Wesberry v. Sanders, 376 U.S. 1, 18 (1964).

2 See Reynolds v. Sims, 377 U.S. 533, 568 (1964).

3 Technically, the terms "apportionment" and "reapportionment" describe the process of allocating representatives among pre-established districts. The terms "districting" and "redistricting" refer to the process of formulating the boundaries of these districts. See Davis v. Bandemer, 478 U.S. 109, 161 n.1 (1986) (Powell, J., concurring and dissenting). State legislators redistrict (rather than reapportion) state and federal legislative districts. See Dixon, The Warren Court Crusade for the Holy Grail of "One Man-One Vote," 1969 SuP. CT. REv. 219, 219 n.4, cited in Comment, Politics and Purpose: Hide and Seek in the Gerrymandering Thicket After Davis v. Bandemer, 136 U. PA. L. REv. 183, 183 n.1 (1987). Despite these differences, Wesberry and Reynolds are often referred to as reapportionment cases, rather than redistricting cases.

369 U.S. 186 (1962).

- The extent of malapportionment existent in the United States in the early 1960s is described infra notes 140-48 and accompanying text. Legislative resistance to reform 
the Court declared that "the fundamental principle of representative government in this country is one of equal representation for equal numbers of people, without regard to race, sex, economic status, or place of residence within a State." The Court also found the right to vote to be "a fundamental matter in a free and democratic society" as a "preservative of other basic civil and political rights," further ensuring that all qualified persons would be able to exercise the franchise equally in a "free and unimpaired manner." these bold declarations was to raise the "democratic ideals of equality and majority rule" to the status of constitutional requirements. ${ }^{\circ}$ A quarter-century later, this Comment will argue that the Court once again may be forced to intervene, absent imminent reform by Congress and state legislatures, in the realm of electoral participation, this time to remedy the gross inequities that characterize the system of personal registration in the United States.

In the 1988 general election, only $50.16 \%$ of eligible voters cast a ballot, the lowest voter turnout rate since $1924 . .^{10}$ The turnout rate is even lower in off-year elections. ${ }^{11}$ As these figures attest, there has been a precipitous decline in voter turnout in the United States since $1960 .{ }^{12}$ Election scholars have proposed a myriad of possible reasons for the decline in participation. Some critics attribute the decline to institutional causes, such as the decline of party competition. ${ }^{13}$ Others look to

of districting laws is discussed infra notes $149-52$ and accompanying text.

Reynolds, at 560-61 (finding this principle to have been clearly established in Wesberry).

7 Id. at 561-62.

Id. at 562.

- See id. at 565-66; of. Auerbach, The Reapportionment Cases: One Person, One Vote-One Vote, One Value, 1964 SuP. CT. REv. 1, 66-67 (arguing that the principle of one person, one vote is a "logical and desirable concomitant" to the features of universal suffrage and representative assembly indicative of a democracy).

${ }^{10}$ See 50.16\% Voter Turnout Was Lowest Since 1924, N.Y. Times, Dec. 18, 1988 , at A36, col. 1 .

${ }_{11}$ See Crotty, The Franchise: Registration Changes and Voter Representation, in Paths to Political Reform 67 (W. Crotty ed. 1980) (noting that ninety million people did not vote in the off-year election in 1978); Squire, Wolfinger \& Glass, Residential Mobility and Voter Turnout, 81 AM. PoL. ScI. Rev. 45, 45 (1987) (finding that only one-third of the eligible electorate voted in the two years previous to the 1980 general election). In 1986 , the turnout rule was $37.3 \%$, the lowest for a congressional election since 1942. See Voter Turnout is Estimated at 37.3\%, Lowest Since 1942, N.Y. Times, Nov. 8, 1986, at A8, col. 4.

12 See P. Kleppner, Who Voted? The Dynamics of Electoral Turnout, 1870-1980, at 112-14 (1982); Crotty, supra note 11 , at $71-72$ \& table 3.1 . Turnout figures for states electing statewide officeholders during this period parallel the trends in presidential and congressional voting. See id. at 72.

${ }_{13}$ See, e.g., P. KLEPPNER, supra note 12, at 70-82 (finding the downturn in party competition to be the most significant cause of electoral demobilization); Burnham, The Changing Shape of the American Political Universe, 59 AM. PoL. ScI. REv. 7, 22-23 
socio-psychological causes, such as the individual voter's level of education, ${ }^{14}$ her sense of civic duty and obligation, ${ }^{15}$ or her sense of apathy and alienation from the political system. ${ }^{16}$ Finally, after almost a century of academic disinterest, ${ }^{17}$ scholars have begun to focus attention upon voter registration and its effects on voter turnout. ${ }^{18}$

Roughly $35-40 \%$ of eligible Americans are not registered to vote. ${ }^{19}$ Primarily due to nonuniform, archaic, and confusing state registration standards, "Americans must face, and master, the most cumbersome and restrictive registration practices of any country" in the free world. ${ }^{20}$

(1965) (arguing that when the 19th century political order of "complete and intensely party-oriented voting participation" was eroded after 1900, "turnout fell precipitately").

14 See R. WOlfinger \& S. Rosenstone, Who Votes? 23-26, 34-36 (1980); see also A. Campbell, P. Converse, W. Miller \& D. Stokes, The American Voter 475-81 (1960) [hereinafter A. CAMPBELL] (noting the strong relationship between a voter's education and her senses of "political efficacy" and "citizen duty," which are harbingers of voter turnout).

15 See S. Verba \& N. Nie, Participation in America: Political DemocRACY AND SOCIAL EQUALITY 125-37 (1972).

18 See A. Hadley, The Empty Polling Booth 39-42 (1978).

17 See, e.g., Burnham, The Appearance and Disappearance of the American Voter: An Historical Overview in The Disappearance of THE American Voter 125,131 (1978) (noting the lack of critical literature on registration laws until the 1960s); Kelley, Ayres \& Bowen, Registration and Voting: Putting First Things First, 61 AM. Pol. Scr. REv. 359, 359 (1967) (finding that until recently, most students of voting have paid little attention to the subject of registration).

${ }_{18}$ See, e.g., P. Kimball, The Disconnected (1972); F. Piven \& R. Cloward, Why AMERICANS Don'T Vote (1988); Crotty, supra note 11; Kelley, Ayres \& Bowen, supra note 17; Rosenstone \& Wolfinger, The Effect of Registration Laws on Voter Turnout, 72 AM. PoL. SCI. REv. 22 (1978); Stone, Voter Registration: Context and Results, 17 URB. LAW. 519 (1985).

19 Accurate figures of the number of registered voters are difficult to ascertain due to flaws affecting each side of the percentage computation which would determine a registration percentage. See Squire, Wolfinger \& Glass, supra note 11, at 46. The numerator-the number of votes cast-is somewhat low in that it excludes spoiled ballots, people who go to the polls but do not vote for a presidential candidate, and certain write-in votes that are not counted. See id. However, the Census Bureau has found that counting all such ballots would only increase turnout by $1-2 \%$. See id. The denominator-the number of people registered to vote-is high in that it includes high numbers of "deadwood" registrants (registered voters who have died or moved and have not been purged from local rolls), persons claiming to be registered when in fact they are not, and samples underrepresenting lower-income citizens whose registration rates are low. See F. Piven \& R. Cloward, supra note 18, app. A at 256-59. Factoring in these variables, Piven and Cloward recalculated the Census Bureau's Current Population Survey (Census Bureau/CPS) figures to come out with a 1984 national registration level of $63-64 \%$. See id. app. A at 258. Other commentators have come up with similar figures. See, e.g., Stone, supra note 18, at 520 (finding the rate of unregistered Americans to number from $35-40 \%$ ).

Mathematical calculations done by the author, based upon returns from the 1988 general election, see supra note 10 and accompanying text, yield a higher rate of nonregistered Americans: $40-43 \%$ of the eligible electorate. See infra note 156 and accompanying text.

$$
{ }_{20}^{\circ} \text { Grotty, supra note 11, at } 69 .
$$


The vast majority ${ }^{21}$ of states continue to maintain registration deadlines of up to fifty days before an election, ${ }^{22}$ and authorize restrictive registration practices such as inconvenient registration sites and hours. ${ }^{23}$ These practices have led many commentators and scholars to acknowledge that the requirement of personal registration in the United States is at least one cause of low voter turnout. ${ }^{24}$

Critical legal analyses of the registration system in the United States have demonstrated that contemporary registration laws could be subject to successful equal protection and statutory challenges. ${ }^{25}$ This

21 Four states do not impose rigid registration deadlines. North Dakota does not require registration. See N.D. CENT. CODE $\S 16.1-02$ (1981). Three other states, Maine, Minnesota, and Wisconsin, allow for election day registration. See ME. REv. STar. AnN. tit. 21-A, $\S 122(4)$ (Supp. 1988); Minn. Stat. AnN. $§ 201.061$ (3) (West Supp. 1989); WIS. STAT. ANN. $\S 6.29(2)(a)$ (West 1986 \& Supp. 1988).

22 State registration deadlines range from five days in Utah, see UTAH CodE ANN. $\S 20-2-6$ (Supp. 1988), to the fifty day registration deadline in Arizona. See Ariz. Rrv. Stat. ANN. § 16-120 (West Supp. 1988).

${ }^{23}$ For a description of restrictive registration practices as well as their effects, see infra notes 78-100 and accompanying text.

24 See, e.g., A. CAMpbell, supra note 14, at 281-82 (noting correlation between "restrictive" election laws and variability in voter turnout); K. PhIllips \& $P$. Blackman, Electoral. Reform and Voter Participation 52-53 (1975) (though disputing that federal registration reform would be a panacea for low voter turnout, estimating that federally assisted national registration would increase turnout by 5$10 \%$ ); F. Piven \& R. Cloward, supra note 18 , at 17-18 (maintaining that voter registration procedures are the "linchpin" of the distorted rates of voter turnout); $R$. WOLFINGER \& S. ROSENSTONE, supra note 14, at 73 (projecting that reform of registration laws would increase national voter turnout by 9.1\%); Burnham, The Turnout Problem, in Elections American Style 108 (A.J. Reichley ed. 1987) ("[F]irst-rate empirical work has demonstrated that personal registration systematically reduces turnout."); Glass, Squire \& Wolfinger, Voter Turnout: An International Comparison, 6 Pub. OpINION 49, 52-53 (Dec./Jan. 1984) (finding lower rates of voter turnout in the United States than in Europe explained most easily by tougher registration procedures); Guinier, Keeping the Faith: Black Voters in the Post-Reagan Era, 24 Harv. C.R.-C.L. L. REv. 393, 418 (1989) (stating that registration requirements "primarily serve to reduce voter participation among all citizens, especially minorities"); Kelley, Ayres \& Bowen, supra note 17, at 362 ("[R]egistration requirements are a more effective deterrent to voting than anything that normally operates to deter citizens from voting once they have registered, at least in presidential elections.").

${ }^{25}$ See, e.g., Note, Eradicating Racial Discrimination in Voter Registration: Rights and Remedies Under the Voting Rights Act Amendments of 1982, 52 FORDHAM L. Rev. 93, 109-22 (1983) [hereinafter Note, Eradicating Racial Discrimination] (arguing that the 1982 amendments to the Voting Rights Act create an affirmative duty upon the states to excise election procedures, such as certain aspects of voter registration, that perpetuate the effects of past racial discrimination); Comment, Access to Voter Registration, 9 HARV. C.R.-C.L. L. REv. 482, 494-518 (1974) (detailing possible equal protection, due process, and fifteenth amendment challenges to registration laws that burden the exercise of the franchise, especially as to minorities); Note, Voter Registration: A Restriction on the Fundamental Right to Vote, 96 YALE L.J. 1615, 1617-40 (1987) [hereinafter Note, Voter Registration] (arguing that registration laws are vulnerable under the fundamental rights strand of equal protection in that they do not serve a "compelling state interest" nor employ the "least restrictive means"). 
Comment goes one step further, arguing that the Court soon will be forced to take affirmative action to rectify the infirmities that characterize the system of personal registration in the United States, similar to the affirmative action taken by the Court in the early 1960s when confronted with gross malapportionment. Part I traces the history of registration laws in the United States to the present day, demonstrating that such laws have had an inherent and continuing disenfranchising effect. Part II notes that when confronted with another significant problem in the electoral realm, that of gross malapportionment, the Court intervened to forge the principle of one person, one vote. It then identifies two "critical features" of malapportionment that compelled judicial intervention: the rapid increase in inequality among districts over time, and legislative self-interest in resisting districting reform. Part III demonstrates that these two "critical features" similarly are present in the realm of voter registration. First, it notes that the rate of unregistered Americans is downwardly spiralling over time, and will soon reach crisis proportions, if it has not done so already. Second, it argues that Gongress and state legislatures have a self-interest in rejecting registration reform, as legislators are loathe to redefine the electorate that voted them into office. Part IV concludes by arguing that due to the unremedied presence of these "critical features," the Gourt soon will be forced to intervene in the realm of voter registration. First, it reviews the constitutional arguments that could serve as the underlying bases to judicial intervention. Second, it argues that the Court must remedy the infirmities of the present system of voter registration by requiring uniform voter enrollment by the government at regular intervals, thereby transferring the burden of registration from the individual to the state.

\section{History and Effects of Registration Laws in the UNITED STATES}

Registration laws in the United States historically have denied qualified voters equal access to the ballot. This Comment divides an analysis of those laws into two parts. Part A traces the history and disenfranchising nature of registration laws in the United States. Part $B$ analyzes registration laws currently in force, concluding that despite reforms, such laws continue to inhibit many qualified voters from the ballot.

\section{A. History of Registration Laws in the United States}

Most laws requiring the personal registration of voters in the United States have been in existence only since the late nineteenth cen- 
tury. ${ }^{26}$ Prior to 1860 , only a few New England states ${ }^{27}$ and certain cities $^{28}$ required any form of registration. ${ }^{29}$ It was only as urbanization increased geometrically during the mid-nineteenth century ${ }^{30}$ that registration laws aimed at preventing voter fraud were passed in many northern states, often with the law being applicable only to large cities. $^{31}$ Most of these early laws, however, did not require personal registration, and thus were ineffective at curbing voter fraud. ${ }^{32}$

At the end of the nineteenth century, most states either introduced or strengthened existing voter registration laws. ${ }^{33} \mathrm{~A}$ key feature of these new statutes was the requirement of personal registration, which "shifted the burden of establishing eligibility from the state to the individual." ${ }^{34}$ Although the ostensible goal of these strengthened registra-

${ }^{26}$ See Kelley, Ayres \& Bowen, supra note 17, at 374.

${ }^{27}$ Massachusetts enacted the first registration law in 1800 . See J. HARRIS, REgistration of Voters IN THE UNITED STATES 65 (1929) (citing Acts and Laws of Massachusetts, $1800, \mathrm{Ch}$. 74). The law requiring registration was upheld by the Massachusetts Supreme Judicial Court in Capen v. Foster, 29 Mass. (12 Pick.) 485 (1832). Connecticut and Maine also adopted early registration systems. See F. PIVEN \& R. Gloward, supra note 18 , at 88 (citing R. Carlson, The Effect of Voter RegisTRATion Systems on Presidential Election Turnout in Non-Southern STATES, 1912-1924, at 105 (1976)).

${ }_{28}$ Pennsylvania enacted a registration law in 1836 that was applicable to the city of Philadelphia. See J. HARRIS, supra note 27, at 67 (citing 1835-36 Pa. Session Laws $436,441-44, \S \S 40-50$ ). In 1840, a registration law was enacted in New York which applied to New York City. See id. at 71 (citing 1840 N.Y. Session Laws Ch. 78 \& $361)$. However, this law was repealed in 1842. A more limited registration law was enacted by South Carolina in 1819 , requiring registration in the city of Columbia for the election of warden and intendant. See id. at 67 (citing 1819 S.C. Acts of the General Assembly, p. 16).

${ }_{29}$ See id. at 72; Converse, Change in the American Electorate, in The Human Meaning of Social Change 263, 283 \& n.34 (A. Campbell \& P. Converse eds. 1972).

This is not to suggest, of course, that there existed universal suffrage before registration laws were enacted. States had always possessed the power to proscribe voter qualifications, which "typically concerned sex, age, place of residency, duration of residency, property, wealth, freeman status, and race." Comment, supra note 25, at 485. Blacks were totally disenfranchised before the Civil War in all but six northeastern states, see Derfner, Racial Discrimination and the Right to Vote, 26 VAND. L. Rev. 523,525 (1973), and were only guaranteed suffrage with the passage of the fifteenth amendment in 1870 . See U.S. CoNsT. amend. XV. Women were denied the franchise until the passage of the nineteenth amendment in 1920. See U.S. ConST. amend. XIX.

${ }^{30}$ See, e.g., K. Phillips \& P. BlaCKMan, supra note 24, at 7 (noting that urbanization increased from 10 percent in 1840 to almost 30 percent in 1880 ).

${ }_{31}$ See J. HARRIS, supra note 27 , at 72. Harris provides a thorough review of the advent and passage of registration laws in the states of New York, Pennsylvania, and Illinois. See id. at 72-85.

${ }_{32}$ See, e.g., id. at 65-66 (noting that "early registration laws were ineffective against corrupt and powerful political machines"); Converse, supra note 29, at 283 (finding that absent personal registration, "ward heelers" drew up registration lists, so fraud was not cured).

${ }^{33}$ See J. HARRIS, supra note 27, at 65; Converse, supra note 29, at 283-84.

$34 \mathrm{P}$. KLEPPNER, supra note 12 , at 60 . A related revision was the change from 
tion laws was to increase protection against vote corruption, ${ }^{36}$ an illicit goal was disenfranchisement, directed against blacks in the South and new immigrants from southern and eastern Europe in the North and Midwest. ${ }^{36}$ As one prescient commentator has noted, "[t]here are certain broad themes which link the origins of all such [registration] legislation together. To a very great degree, it was motivated by racism ग37

The new registration laws had a marked effect on voter turnout rates throughout the nation. ${ }^{38}$ In the South, most blacks and many poor

permanent registration to either periodic or annual registration. See F. PIVEN \& R. Cloward, supra note 18 , at 90 .

${ }^{35}$ See, e.g., J. HARRIs, supra note 27 , at 72 ("The extension of registration was to come after the rapid growth of cities following the Civil War, the great influx of immigrants, and the growth of cities following the Givil War, the growth in power and corruption of the political machines . . ."); P. KLEPPNER, supra note 12, at 58 (finding registration reform to be part of "a concerted and successful effort to rationalize and regulate the conduct of elections and the role of political parties in the electoral process").

A few commentators claim that progressive reform was the primary intent of the new registration laws. See, e.g., Converse, supra note 29, at 286 ("[T] forces of reform, bent on cleaning up the fraud continuing to haunt voting process in the United States, lent their weight to the demands of the cities for broader registration control."); Rusk, Comment: The American Electoral Universe: Speculation and Evidence, 68 AM. Pol. Scr. REv. 1028, 1045 (1974) (arguing that the intended effect of the new registration system was "to end vote corruption"). However, the strength of this argument depends upon the actual prevalence of widespread vote fraud, a question that is the focus of much scholarly debate. Compare Converse, supra note 29, at 282 (noting a widespread recognition of voter fraud in this period) and Rusk, supra, at 1032-33 (finding the existence of weak registration laws and the unofficial ballot, both integral to vote corruption, to be expressly implemented by the political parties to control the vote) with P. KLEPPNER, supra note 12, at 59 (arguing that voter fraud was episodic rather than routine) and Burnham, supra note 17, at 126 (rejecting as "unprovable" and "unreasonable" the notion of "universal corruption" of the voting process).

${ }^{36}$ See W. Crotty, Political Reform and the American Experiment 1516 (1977); K. Phillirs \& P. Blackman, supra note 24, at 7-8; F. Piven \& R. Cloward, supra note 18, at 78-95; Burnham, A Political Scientist and Voting-Rights Litigation: The Case of the 1966 Texas Registration Statute, 1971 WASH. U.L.Q. 335, 336; Voting Rights Act: Runoff Primaries and Registration Barriers: Hearings on the 1982 Amendments of the Voting Rights Act of 1965 Before the Subcomm. on Civil and Constitutional Rights of the House Comm. on the Judiciary, 98th Cong., 2d Sess. 136 (1985) [hereinafter Hearings on the 1982 Amendments] (testimony of Lani Guinier, Head of the Voting Rights Litigation Project of the NAACP Legal Defense \& Educational Fund, Inc.).

Even commentators who profess that reform was the primary goal of the new registration laws recognize that there also existed a disenfranchising intent in these enactments. See, e.g., Converse, supra note 29, at 297 (stating that registration laws were viewed as a means "to protect the white Anglo-Saxon Protestant culture from further subversion by the hordes of new immigrants from southern and eastern Europe. While 'morality' made a much finer platform than 'our culture is better than yours,' the nativist implications of the reforms were widely perceived").

${ }^{37}$ Burnham, supra note 36, at 336.

38 Though some scholars argue that other forces were the primary cause of the 
whites were eliminated from voter rolls. ${ }^{39}$ Since the fifteenth amendment prohibited the overt disenfranchisement of blacks, ${ }^{40}$ the South utilized more sophisticated and oblique schemes. ${ }^{41}$ In addition to personal registration, southern states instituted an "interlocking network of legal devices," ${ }^{\prime 2}$ including literacy tests, poll taxes, eight-box laws, and the secret or "Australian ballot," to achieve disenfranchisement. ${ }^{43}$ Despite the wide-spread use of these more sophisticated schemes, however, the arbitrary administration of the registration system remained the primary mode of disenfranchisement. ${ }^{44}$ As one commentator has noted, "[ $t]$ he key disfranchising features of the southern registration laws were the amount of discretion granted to the registrars, the specificity of the information required of the registrant, the times and places set for registration, and the requirement that a voter bring his registration certificate to the polling place." 45

The effect of personal registration had a similar effect in the North and the Midwest. ${ }^{48}$ Registration statutes passed in these areas

turnout decline at the end of the twentieth century, they nevertheless recognize the disenfranchising effects of registration laws. Walter Dean Burnham, for example, argues that the fall in turnout was due to the collapse of intense party competition, especially after the 1896 election. See Burnham, supra note 13, at 22-23. However, Burnham acknowledges that "[t]he basic legal devices which were adopted-particularly the device of personal registration-without question contributed to the massive decline in voter participation after 1900." Burnham, supra note 17 , at 141 .

39 See, e.g., J.M. Kousser, The Shaping of Southern Politics 49-50 (1974) (citing examples in South Carolina and Louisiana in which significant portions of the black as well as white populations were disenfranchised); K. PHill.IPS \& $P$. BLACKMAN, supra note 24 , at 8 (citing statistics demonstrating marked drops in voter turnout in many southern states); Derfner, supra note 29, at 542 (noting that "[b]lacks were, with rare exceptions . . . wholly eliminated from the political process").

Harris details an example of this discrimination, in which a black attorney, a graduate of Harvard, was denied registration in Mississippi by the precinct registrar (a blacksmith) for failing to give a "reasonable" interpretation of the due process clause after a discourse that demonstrated "considerable learning and ability." J. HARRIS, supra note 27 , at 157 n.24.

to Section I of the fifteenth amendment to the United States Constitution reads: "The right of citizens of the United States to vote shall not be denied or abridged by the United States or by any State on account of race, color, or previous condition of servitude." U.S. CoNST. amend. XV, § 1.

1 A further reason for the more sophisticated schemes was the fact that methods such as violence and fraud, aimed at keeping blacks as well as Republicans from the ballot, threatened a return of federal intervention. See J.M. KousSER, supra note 39, at 45-46; F. Piven \& R. Cloward, supra note 18, at 79.

12 Burnham, supra note 36 , at 336.

13 For a thorough review of the types and effects of these laws, see J.M. KOUSSER, supra note 39 , at 45-72.

41 See, e.g., J. HARRIS, supra note 27, at 157 ("The Negro in the South has been disfranchised largely through the arbitrary administration of registration rather than by the literacy requirement and other suffrage qualifications.").

45 J.M. Kousser, supra note 39 , at 48.

46 See Burnham, Rejoinder to Comments by Philip Converse and Jerrold Rusk, 
were directed primarily against the populations of urban areas, indicating a strong distrust of city political " 'machines' and their ethnic clienteles." ${ }^{\text {47 }}$ As time went on, however, the laws were extended to smaller cities and even some rural areas. ${ }^{48}$ These registration procedures were "exceedingly expensive, cumbersome, and inconvenient,"49 and many citizens who were only marginally involved in the voting process were "priced out of the system" as the costs of participation had become too great. ${ }^{50}$

The Supreme Court was not immediately receptive to constitutional challenges to state registration laws. Indeed, the Court upheld almost every statute with a disenfranchising effect for a period extending half a century. ${ }^{51}$ At the turn of the century, the Court rejected five challenges to various state registration schemes, basing each decision on procedural grounds. ${ }^{52}$ The Court also upheld as constitutional many restrictive election laws, including the poll $\operatorname{tax}^{\mathrm{B3}}$ the literacy test, ${ }^{54}$ and white primaries that were not mandated by the state. ${ }^{55}$

Gradually, however, the Court began to invalidate the more egregious election laws. As early as 1915, the Court struck down the use of the grandfather clause, which had served to protect whites from being

68 AM. Poi.. Sci. Rev. 1050, 1057 (1974); see also Burnham, supra note 36, at 336 (finding southern election schemes to be "paralleled in a less extreme form" in the North).

47 Burnham, supra note 36 , at 336-37.

48 See J. HaRRIS, supra note 27, at 72 .

19 Id. at 66.

so $\mathrm{P}$. KLEPPNER, supra note 12 , at 60 . In economic terms, "every rational man decides to vote just as he makes all other decisions; if the returns outweigh the cost, he votes; if not, he abstains." A. Downs, An Economic Theory of Democracy 260 (1957).

${ }^{31}$ See Derfner, supra note 29, at 541. The only exceptions were registration schemes whose applications were explicitly or "inescapably" limited precisely to blacks. See id. at 541-42.

52 See Jones v. Montague, 194 U.S. 147, 153 (1904) (finding challenge to Virginia registration laws to be moot, as the election in which the plaintiffs wished to vote had already taken place); Selden v. Montague, 194 U.S. 153, 154 (1904) (same); Giles v. Teasley, 193 U.S. 146, 165-66 (1904) (denying review to an Alabama Supreme Court decision that rejected a challenge to Alabama registration laws and practices); Williams v. Mississippi, 170 U.S. 213, 213-15, 225 (1898) (denying appeal of a criminal conviction by an all-white jury by plaintiff who charged that blacks had been intentionally excluded from jury duty by means of their intentional exclusion from voter rolls); Mills v. Green, 159 U.S. 651, 657-58 (1895) (finding challenge to South Carolina registration laws to be moot, as the election in which the plaintiffs wished to vote had already taken place); see also Derfner, supra note 29, at 539-41 (providing case backgrounds).

${ }_{63}$ See Breedlove v. Suttles, 302 U.S. 277 (1937), overruled, Harper v. Virginia Bd. of Educ., 383 U.S. 663 (1966).

54 See Lassiter v. Northampton Bd. of Elections, 360 U.S. 45 (1959).

ss See Grovey v. Townsend, 295 U.S. 45 (1935), overruled, Smith v. Allwright, 321 U.S. 644 (1944). 
disenfranchised by the literacy test. ${ }^{56}$ The Court also began to chip away at the "most effective and simplest way of disfranchising blacks"-the white primary. ${ }^{57}$ In 1927, the Court invalidated white primaries ordered by the state; ${ }^{.8}$ then, in 1944, the Court outlawed the white primary completely. ${ }^{58}$ Black registration in the South subsequently increased at a moderate rate throughout the early $1950 \mathrm{~s}^{60}$

With the downfall of the white primary, most southern states returned to the use of discretionary registration systems as the primary means of discrimination. In "giving substantial discretion to the local white registrar, who was . . .'a law unto himself in determining the citizen's possession of literacy, understanding, and other qualifications,' legislators could restrict black registration with a minimum of effort."61 Other states turned to different means: Alabama adopted a state constitutional amendment, known as the Boswell Amendment, which mandated literacy and good character tests, among others, ${ }^{62}$ Mississippi enacted a double literacy and understanding test, ${ }^{\mathbf{B 3}}$ and Louisiana implemented an organized effort to purge black voters from voter rolls on the basis of technical registration infractions. ${ }^{64}$ As a result of these restrictive measures, progress in black registration in the late 1950s was "limited at best."

The major advances in breaking down the barriers to the ballot finally were forged in the 1960s. Through the sustained success of the Civil Rights Movement, the Civil Rights Act of $1964^{66}$ and, more im-

se See Guinn v. United States, 238 U.S. 347, 357-68 (1915). The Court also invalidated an attempted modification of the grandfather clause in 1939. See Lane v. Wilson, 307 U.S. 268 (1939).

87 Derfner, supra note 29 , at 542.

${ }^{88}$ See Nixon v. Herndon, 273 U.S. 536, 541 (1927).

59 See Smith v. Allwright, 321 U.S. 649, 664 (1944). The Court extended the rule of Smith to prohibit racially restrictive pre-primary elections in Terry v. Adams, 345 U.S. 461 (1953).

${ }^{60}$ See D. Garrow, Protest at Selma: Martin Luther King, Jr., and the Voting Rights ACT of 1965, at 9 (1978). (1949)).

61 Id. at 8 (quoting V.O. Key, Southern Politics in State and Nation 563

${ }_{62}$ See id. The Boswell Amendment was subsequently ruled unconstitutional by a three-judge district court panel, who found the Amendment to be designed to achieve the goal of granting to local registrars the opportunity to discriminate, which they were in fact doing. See Davis v. Schnell, 81 F. Supp. 872 (S.D. Ala.), aff'd mem. 336 U.S. 933 (1949).

${ }^{63}$ See D. Garrow, supra note 60, at 9-10.

64 See id.

6s Id. at 10.

${ }^{66}$ See Pub. L. No. 88-352, 78 Stat. 241 (codified at 42 U.S.C. $\S 1971$ (1982)). For a discussion of the aims and effects of the Civil Rights Act, see Derfner, supra note 29 , at 547-50. 
portantly, the Voting Rights Act of $1965^{67}$ were enacted. Due in large part to the effects of these affirmative congressional mandates, states have substantially relaxed voter registration requirements since $1960{ }^{68}$ And when the Supreme Court declared the right to vote to be fundamental in Reynolds $v$. Sims, ${ }^{69}$ it opened the door for the invalidation of many of the more blatant disenfranchisement techniques. The Court would ultimately strike down both the poll $\operatorname{tax}^{70}$ and durational residency requirements, ${ }^{71}$ and also would uphold congressional power to proscribe literacy tests. ${ }^{72}$

The abolition of such devices as the poll tax and the literacy test, however, has not resulted in a substantial and sustained rise in registration rates; other impediments to the ballot have remained

67 See Pub. L. No. 89-110, 79 Stat. 445 (codified as amended at 42 U.S.C. $\S \S 1971,1973$ to $1973 \mathrm{bb}-1$ (1982)). It is far beyond the scope of this Comment even to attempt an analysis of the dramatic impact that the Voting Rights Act has had in the last twenty-four years. Instead, the words of one voting rights commentator will have to suffice:

The Act was an immediate success. The effects on voters, and registrars, of suspending literacy tests and of installing federal examiners to register voters in problem areas was electric. By 1967, the percentage of blacks registered in the covered states has risen sharply, and has continued to rise to the point where black registration is not far below white registration in many parts of the South.

Derfner, supra note 29, at 552.

The fact that the Voting Rights Act was introduced in part as a response to violent attacks by southern authorities on blacks and whites marching to secure voting rights for all citizens, see A. Thernstrom, Whose Votes Count? Affirmative Acrion AND Minority Voting Rights 2 (1987), is a testament to the courage and tenacity of all those involved in the Civil Rights Movement.

68 See Burnham, supra note 24 , at 109 \& n.26.

69377 U.S. 533, 561-62 (1964).

${ }^{20}$ See Harper v. Virginia Bd. of Educ., 383 U.S. 663 (1966). The twenty-fourth amendment, enacted in 1964, prohibited poll taxes in federal elections. See U.S. CoNST. amend. XXIV. Harper invalidated any remaining poll taxes in state and local elections.

71 See Dunn v. Blumstein, 405 U.S. 330, 336 (1972).

72 In South Carolina v. Katzenbach, 383 U.S. 301, 334 (1966), the Court upheld a Voting Rights Act ban of literacy tests and similar devices for a period of five years in areas of demonstrated past discrimination via Congress's fifteenth amendment enforcement power. In Katzenbach v. Morgan, 384 U.S. 641, 652-53 (1966), the Court upheld a similar Voting Rights Act provision that served to outlaw New York's requirement of literacy in English as a prerequisite to voting as it applied to Puerto Ricans with certain education qualifications via Congress's fourteenth amendment enforcement power. Finally, in Oregon v. Mitchell, 400 U.S. 112, 131-34 (1970), the Court upheld the constitutionality of a provision of the Voting Rights Act Amendments of 1970 which banned the use of literacy tests in any state as a prerequisite to voting.

In upholding congressional power to proscribe literacy tests in these rulings, the Court did not address their constitutional viability, thus distinguishing and not overruling Lassiter v. Northampton Bd. of Elections, 360 U.S. 45 (1959), which had found literacy tests to be constitutional. 
untouched. ${ }^{73}$

\section{B. Contemporary Registration Laws}

Registration laws currently in force in the United States, though not explicitly geared toward disenfranchisement, still retain many of the features that earlier served to disenfranchise numerous Americans. A few states have progressed from entirely rigid voter registration laws and deadlines. North Dakota does not require registration, ${ }^{74}$ and three other states allow for election day registration. ${ }^{75}$ Twenty-one other states and the District of Columbia allow for mail registration, ${ }^{\mathbf{7 6}}$ which can serve as a means of increasing registration. ${ }^{77}$ These states remain the exception, however, rather than the rule.

Forty-six states and the District of Columbia maintain registration deadlines that can range up to fifty days before an election. ${ }^{78}$ Such deadlines prevent those citizens whose interest in an election peaks as the election day approaches from casting a ballot, as by then it is likely

${ }^{73}$ See Terchek, Political Participation and Political Structures: The Voting Rights Act of 1965, 41 Phylon 25, 26-27 (1980). In terms of black registration, Derrick Bell has noted that "[t]he ravages of the first disfranchisement of black voters during the post-Reconstruction years remain apparent." D. BELL, RACE, RACISM AND AMERICAN LAW \$ 4.7, at 154 (2d ed. 1980).

74 See N.D. CENT. CoDE $\S 16.1-02$ (1981) (registration law repealed by 1951 N.D. Laws, ch. $264, \S 3$ ).

${ }^{75}$ See Me. Rev. Stat. Ann. tit. 21-A, $\S 122(4)$ (West Supp. 1988); Minn. Stat. ANN. § 201.061(3) (West Supp. 1989); Wis. Stat. ANN. § 6.29(2)(a) (West 1986 \& Supp. 1988).

Oregon recently repealed its election day registration law. It now requires registration 21 days before election, except in the case of those who moved to the state less than 21 days before the election. See OR. REv. STAT. $\$ 247.025$ (1988).

${ }^{76}$ See Alaska STat. § 15.07.050 (1988); Cal. Elec. Code $§ 303$ (West 1977); Del. Code AnN. tit. 15, § 2012 (1981); D.C. Code ANN. \& 1-1311(c)(2) (1981); Haw. Rev. Stat. § 11-16 (1985); Iowa Code ANN. § 48.3 (West Supp. 1988); Kan. Stat. ANN. § 25-2309 (1986); Ky. Rev. Stat. ANN. § 116.045(4)(b) (Michie/ Bobbs-Merrill 1982 \& Supp. 1988); MD. ANn. Code art. 33, § 3-1(c) (1986); Minn. Stat. ANN. § 201.061(1) (West Supp. 1989); Mont. Code AnN. § 13-2-203 (1987); Neb. Rev. Stat. § 32-221(c) (1988); N.J. Stat. ANN. § 19.31-6.3 (West Supp. 1988); N.Y. Elec. Law § 5-210(1) (McKinney 1978); Ohro Rev. Code ANN. $\S$ 3503.11(b) (Anderson 1988); OR. Rev. STat. § 247.012(1) (1986); Pa. Stat. AnN. tit. 25, $\S \S 623-19.1$ (a), 951-17.1(a) (Purdon Supp. 1988); TENN. Code ANN. § 2-2115 (1985); Tex. Elec. Code ANN. $\S 13.002$ (Vernon 1986); Utah Code ANN. $\S 20-2-7(2)$ (Supp. 1988); W. VA. Code $\S ~ 3-2-41$ (Supp. 1988); Wis. Stat. ANN. $\S 6.30(4)$ (West 1986).

${ }_{77}$ See Voter Registration by Mail: Hearings on S. 1177 Before the Senate Comm. on Post Office and Civil Service, 94th Cong., 1st Sess. 369 (1975).

${ }^{78}$ As noted supra note 22 , Arizona maintains a fifty-day registration deadline. The majority of the other forty-five states and District of Columbia mandate registration deadlines of twenty to thirty days before an election. See League of WOMEN Voters Education Fund, Easy Does It: Registration and Absentee Voting Procedures by State (1984) (chart). 
too late to register. ${ }^{78}$ Compounding this problem is the fact that registration is often limited to a single central location in a county-often the county courthouse ${ }^{80}$ - during working hours. ${ }^{81}$

Another impediment to the franchise is the fact that whenever one moves, "whether it is down the street, to a nearby town, or across the country, it is necessary to register anew." marked downturn in participation for mobile Americans who have moved within the past two years. ${ }^{83}$ Furthermore, it serves as a linchpin for abusive and partisan election practices aimed at excluding from the polls those voters who have moved within the jurisdiction and unwittingly failed to reregister. ${ }^{84}$

Dual registration, the technique of requiring citizens to register in two different jurisdictions (typically a county and a municipality) also impedes registration. ${ }^{85}$ Presently, only one state explicitly prohibits

79 See Subcomm. on Givil and Constitutional Rights, Comm. ON THE JuDiciary, 98th Cong., 2D SESS., Report: After the Voting Rights ACt: RegisTration Barriers 5 (Comm. Print 1984) [hereinafter RePort: AfTer the Voting RIGHrs ACT]; Rose, Citizen Participation in the Electoral Process: American Practice in a European Perspective, in The Disappearance of THE American Voter, supra note 17, at 177 app. C at 179; Squire, Wolfinger \& Glass, supra note 11, at 45.

80 For many blacks in the South, the courthouse building is a "psychological barrier, for it stands as a symbol of the historic oppression of black people." REPORT: AFTER THE Voting RIGHTS ACT, supra note 79, at 5 . This fact is evidenced by the testimonial of one southern voting rights activist: "I knew blacks and some whites, when you say courthouse, they freeze up, they been scared off." Hand \& Douglas, Enough is Enough: Voting Rights Denied, 9 S. EXPOSURe 95, 95 (1981) (interview with Geraldine Sawyer, mayor of a small, unincorporated southern residential community).

81 See Report: After THE Voting Rights ACT, supra note 79, at 2-3. One investigative study of registration practices in several states found that more than onehalf of the 300 registration offices investigated were not clearly identified, one-quarter did not have convenient parking facilities, and more than one-half were not easily accessible by public transportation. See W. CROTTY, supra note 36, at 59 (citing figures from League of Women Voters Education Fund, Administrative Obstacles To Voting (1972)).

82 Squire, Wolfinger \& Glass, supra note 11 , at 46.

${ }^{83}$ See id. at 46, 51-57. In fact, mobile Americans have been found to have a turnout rate consistent with those socioeconomic groups least likely to vote-young people and the uneducated, see id. at 46, despite the fact that movers have the same levels of civic virtue, such as interest in politics, attention to the campaign, concern about the outcome, and political efficacy, as nonmobile Americans. See id. at 50, 61.

84 An example of such abusive tactics occurred on the campus of the University of Pennsylvania before the 1988 general election. Republican ward officials attempted to exclude from voting almost 350 students who had changed campus residences between school years and had failed to reregister. See 350 Votes Nullified by GOP: Registration Rules Violated by Students, Daily Pennsylvanian, Nov. 8, 1988, at 1, col. 3. After an "eleventh hour" appeal, however, an election judge allowed the students to vote. See Students Allowed Votes After Being Disqualified, Daily Pennsylvanian, Nov. 9, 1988, at 1 , col. 4 .

${ }^{8 s}$ See Note, Eradicating Racial Discrimination, supra note 25, at 93 \& n.6. 
dual registration, ${ }^{86}$ while several other states leave local officials discretion to invoke this requirement. ${ }^{87}$ Forty states and the District of Columbia also utilize "purge statutes" which, though necessary in some form to ensure the integrity of the voting rolls, often remove previously registered citizens who have already met the burden of registration but who have failed to exercise the franchise within a given time period. ${ }^{88}$ This confusing maze of registration laws requires a qualified voter

to ascertain (at a minimum) where and when to obtain the registration form, how to fill it in, whether supporting documents are needed, what the deadline is, and whether a declaration of party affiliation is required. For even a motivated citizen, these requirements present administrative obstacles that are hard to overcome. ${ }^{89}$

Finally, similar to the situation existent when registration laws were first enacted, the discretionary power granted to local registrars often serves to impede registration rather than further it. ${ }^{90}$ Many states allow local registrars full discretion to establish satellite sites ${ }^{91}$ or to extend polling hours. ${ }^{92}$ Many states also give the local registrar discretion to appoint deputy registrars; ${ }^{93}$ this practice results more often in

86 See Fla. Star. ANN. § 98.041 (West 1982).

${ }^{87}$ See Note, Eradicating Racial Discrimination, supra note 25, at 93-94 n.7.

88 See Note, The Purging of Empowerment: Voter Purge Laws and the Voting Rights Act, 23 HARv. C.R.-C.L. L. REv. 483, 550-51 app. A (1988) (listing notice requirements and triggering periods required by state voter purge statutes).

${ }^{89}$ Stone, supra note 18 , at 522.

90 As noted supra note 44 and accompanying text, the key disenfranchising features of many registration laws at the turn of the century were the discretionary power of the registrar and inconvenient times and places for registration, among others.

91 See, e.g., La. Rev. Stat. ANN. § 18:133(D) (West 1979); MD. Elec. Code ANN. § 3-2(c)(1986); Mich. Comp. Laws AnN. § 168.498(1)(2) (West Supp. 1988); TENN. CODE ANN. § 2-2-111(a) (1985).

${ }_{92}$ See, e.g., La. Rev. StaT. ANN. \& 18:134(A)-(C) (West 1979 \& Supp. 1988); MD. Elec. Code ANN. § 3-2(a) (1986); Mich. Comp. Laws ANN. § 168.498(1)-(2) (West Supp. 1988); Neb. Rev. Stat. $§ 32-216.01$ (1988); Pa. Stat. AnN. tit. 25, § 951-16(a) (Purdon Supp. 1988); S.C. Code ANN. § 7-5-140 (Law. Co-op Supp. 1988); Tex. Elec. Code AnN. § 12.004(b) (Vernon 1986); VA. Code ANN. § 24.149 (Supp. 1988).

${ }_{93}$ See, e.g., Ala. Code $\S 17-4-158$ (1987); Fla. Stat. ANN. § 98.271(1)(2) (West Supp. 1988); Ga. Code ANN. § 21-3-120(d) (Supp. 1988); Idaho Code $\S 34-$ 209(1) (1981); Iowa Code AnN. $\$ 48.4$ (West Supp. 1988); Me. Rev. Stat. AnN. tit. 21-A, § 102 (Supp. 1988); MD. EleC. Code ANN. § 3-10(a) (1986); MASS. ANN. Laws ch. 51, §§ 22, 22A (Law, Co-op 1978); Mo. ANN. STAT. § 115.143(2) (Vernon Supp. 1989); Neb. Rev. Stat. \& 32-208 (1988); Nev. Rev. Stat. AnN. $\S 293.505(2)$ (Michie Supp. 1988); N.J. STAT. ANN. § 19:31-2 (West Supp. 1988); OR. Rev. STAT. $\S 246.250$ (1) (1986); PA. Stat. ANN. tit. 25, $\S 951-5$ (a) (Purdon 1963); R.I. GEN. LAws § 17-9-5(a) (1988); S.C. Code ANN. $§ ~ 7-5-20$ (Law. Co-op Supp. 1988); see also LA. Rev. Stat. ANN. $\$ 18: 591$ (West Supp. 1988) (prohibiting temporary deputy registrars and instead calling for immediate appointments to fill va- 
greater power to inhibit registration than in increases in the ease of registration. ${ }^{94}$ These limitations create a multitude of barriers for potential registrants, including conflicts between registration hours and working hours, significant travel to registration sites, and continuing intimidation by local registrars and officials. ${ }^{95}$ In fact, one investigative study of registration practices in the states found local registrars "to be basically unconcerned with the difficulties [of registration], to exercise a great deal of discretion over what they could (or would) do, and to be under no centralized supervision."

Registration requirements thus create a two-tiered election system in the United States, one in which the first hurdle, registering to vote, is "shrouded in obscurity" and often difficult to overcome." As one commentator has noted:

Prospective voters are not educated to deal with [registration requirements]; their attention, like that of the media and of the nation at large, focuses on the election and its outcome. . . . As a consequence, individuals have little knowledge of the two-tiered election process and little sensitivity to

cancies); TenN. CoDE ANN. § 2-12-201(d) (1985) (not permitting volunteers to serve as deputy registrars); VA. CoDE ANN. § 24.1-46(1) (1985) (prohibiting registrars from actively soliciting specific registrants).

94 See RePORT: AfTer the Voting Rights Act, supra note 79, at 3-4 (noting several state and local practices that inhibit rather than foster registration).

${ }^{95}$ See id. at 2-3; Crotty, supra note 11, at 92.

${ }^{86}$ Crotty, supra note 11 , at 92 (utilizing findings from LEAGue of WOMEN Vorers Education Fund, Administrative OBSTACles to Voting (1972); see P. KimBALL, supra note 18, at 297 ("The staffing of registration points is usually under the control of local organizations who sometimes have special interest in excluding potential new voters who might threaten the distribution of power."); Guinier, supra note 24 , at 418 (noting that "many local officials treat the franchise as a privilege which the voter must earn").

The United States Commission on Civil Rights has reported that "minority organizations and private citizens who have attempted to secure more flexible registration procedures reported lack of cooperation or hostility on the part of registration officials." United States Commission on Civil Rights, The Voting Rights Act: UnfulFILLED GOALS 67 (1981). In terms of specific practices of local registrars that serve to retard voter registration, the League of Women Voters Education Fund study found that:

Only eleven percent of the local officials ... published a voter information guide; 28 percent provided no training for poll workers; and in approximately thirty percent of the registration places where bilingual assistance was needed, local officials failed to provide that service. Election officials clearly have the power to make registration and voting procedures easier for citizens. . . by and large, they don't use it.

League of Women Voters Education Fund, supra, at 8.

${ }^{87}$ Squire, Wolfinger \& Glass, supra note 11 , at 45.

${ }^{88}$ See Crotty, supra note 11 , at 69-70. 
the types of demands it will make on them. ${ }^{99}$

Simply put, in the United States, "registration is often more difficult than voting." 100

An analysis of the effects of the system of personal registration on voters is enhanced by a comparison of participatory rates in the United States with those of other western democratic nations. The United States consistently ranks at the bottom of cross-section analyses of voter turnout rates. ${ }^{101}$ Seventeen of twenty-four western nations studied, on the other hand, had participatory rates that exceeded $75 \%{ }^{102}$

The most apparent reason for this differential is the fact that in other western democracies, voting is a collective responsibility in which both the government and the individual citizen are involved in ensuring universal participation in the political process. ${ }^{103}$ Voter registration in these nations is either automatic, activated by citizen identity cards and/or governmental records, or is initiated by governmental canvasses of the electorate. ${ }^{104} \mathrm{Six}$ nations in fact impose penalties upon nonvoters. ${ }^{105}$ The United States is the only western nation that continues to follow the "obsolete" English practice of placing the entire burden of registration upon the individual. ${ }^{106}$

89 Id.

100 Rosenstone \& Wolfinger, supra note 18 , at 22 . In the 1988 general election, $37 \%$ of nonvoters stated that they did not vote because they were not registered, by far the most important reason given for nonvoting. See If Nonvoters Had Voted: Same Winner, But Bigger, N.Y. Times, Nov. 21. 1988, at B16, col. 3; see also Crotty, supra note 11 , at 84 ("By far, the reason given by the greatest number in explaining their nonvoting was registration. Taking the population of nonvoters as a whole, 82 percent said the reason that they did not vote was that they were not registered.").

${ }^{101}$ See, e.g., F. Piven \& R. Cloward, supra note 18, at 5 (citing a Harvard/ $A B C$ News Symposium which ranked the United States twenty-third out of twentyfour western nations); Crotty, supra note 11, at 75-77 (ranking the United States twenty-second out of twenty-three western nations); Glass, Squire \& Wolfinger, supra note 24 , at 50 (ranking the United States twenty-third out of twenty-four western nations).

${ }^{102}$ See sources cited id.

103 See F. Piven \& R. Cloward, supra note 18, at 17; R. Tuxeira, Why Americans Don't Vote: Turnout Decline in the United States, 1960-1984, at 112 (1987); Crotty, supra note 11, at 69.

104 See Glass, Squire \& Wolfinger, supra note 24, at 52.

10 Australia, Belgium, Greece, and Italy impose some form of compulsory voting, as do parts of Austria and Switzerland. See Powell, American Voter Turnout in Comparative Perspective, 80 AM. Pol. Scr. REv. 17, 20 (1986).

${ }^{108}$ See Crotty, supra note 11, at 69; Rose, supra note 79, at 179; Squire, Wolfinger \& Glass, supra note 11, at 45. In Australia and New Zealand, citizens must take the initiative to register, but they are legally required to do so and subject to fines or other penalties for failing to do so. See Powell, supra note 105, at 21. Similarly in France registration is ostensibly left to the voluntary initiative of citizens; however, they are legally required to register in their community and to obtain identification cards, which facilitates registration. See id. 
A common argument that attempts to explain the disparity in participatory rates between the United States and other western democracies holds that it is the result of higher levels of voter alienation and apathy in the United States. Studies consistently have demonstrated, however, that Americans' confidence and pride in their own governmental structure is unparalleled among western nations. ${ }^{107}$ The sense of civic virtue evidenced by American citizens is not limited solely to registered voters. Studies show no difference between voters and nonvoters in terms of their views of a civic duty to vote, or in views that ordinary citizens have a say in what the government does. ${ }^{108}$

The more likely explanation for the disparity in participation rates between the United States and other western nations is the presence of registration restrictions. In the United States, voter turnout is calculated as the percentage of the voting-age population that casts a ballot on election day. When voting rates are calculated based upon the percentage of registered citizens who voted, however, the rate of participation in the United States is comparable to those of other western nations, ranging between $85-89 \% .^{100}$

\section{One Person, One Vote: Judicial Intervention in the REALM OF REDISTRICTING}

In the early 1960 s, the Supreme Court was faced with a similarly monumental problem in the electoral realm that threatened the viability of representative government-the existence of gross malapportionment that had become "alarmingly large and senselessly erratic" throughout the United States. ${ }^{110}$ Part II of this Comment analyzes the Court's in-

107 See, e.g., G. Almond \& S. Verba, The Civic Culture 102 (1963) (finding $85 \%$ of Americans to be proud of their political institutions, compared with $46 \%$ of the Britons, $7 \%$ of the West Germans, and 3\% of the Italians); S. LIPSET \& W. SCHNEIDER, THE Confidence GaP. 410 (rev. ed. 1987) (finding the level of overall confidence in American institutions to be second only to Ireland among western, democratic nations in a 1981 Gallup Poll). As one commentator has noted, "American political attitudes should . . . facilitate more political participation than political attitudes in other democracies." Powell, supra note 105, at 19.

${ }^{108}$ See Ranney, Nonvoting is Not a Social Disease, 6 Pub. OpInion 16, 17 (Oct./Nov. 1983).

${ }_{108}$ See, e.g., F. Piven \& R. Cloward, supra note 18, at 19, app. B at 260-61 (noting Census Bureau/CPS and National Election Study (NES) studies of participatory rates of registered voters that range from a low of $84 \%$ to a high of $89 \%$ in the 1980s); Glass, Squire \& Wolfinger, supra note 24, at 52 (combining same studies to find a participatory rate of $86.8 \%$ ); Squire, Wolfinger \& Glass, supra note 11 , at 47 (same).

110 R. McKay, Reapportionment: The Law and Politics of Equal RePRESENTATION 38 (1965). The breadth and scope of malapportionment existent in the United States in the early 1960 s is set out infra notes 140-48 and accompanying text. 
tervention in the "political thicket" in order to remedy malapportionment. Part A reviews the advent of one person, one vote from Baker $v$. Carr $^{111}$ through Reynolds $v$. Sims. ${ }^{112}$ It then discusses the qualitative dimensions of the rule as applied in federal and state districting schemes. Part B identifies two "critical features" of malapportionment that compelled judicial intervention. First, it describes the rapidly worsening condition of malapportionment over time. Second, it notes that legislative reform was not forthcoming in that legislators had a selfinterest in retaining, rather than reforming, districting schemes.

\section{A. The Rule of One Person, One Vote}

\section{Advent of One Person, One Vote}

In 1962, after sixteen years of resisting equal protection challenges to districting laws, ${ }^{113}$ the Supreme Court intervened in the realm of redistricting in Baker, reflecting a realization of "the manifest need to rectify gross malapportionment."114 Justice Brennan found that redistricting presented a justiciable question, stating that "[j]udicial standards under the Equal Protection Clause are well developed and familiar, and it has been open to courts since the enactment of the Fourteenth Amendment to determine . . . that a discrimination reflects no policy, but simply arbitrary and capricious action."115 The Court subsequently gave meaning to Baker a year later, holding in Gray $v$. Sanders $^{116}$ that a statewide primary system that afforded greater weight to ballots cast in rural areas than to those cast in urban areas

111369 U.S. 186 (1962).

112377 U.S. 533 (1964).

${ }^{113}$ The Supreme Court first rejected an equal protection challenge to a state's districting plan in Colegrove v. Green, 328 U.S. 549 (1946). In Colegrove, the Court found that the districting issue was "of a purely political nature and therefore not meet for judicial determination." Id. at 552. Subsequently the Court summarily refused to consider a number of other redistricting cases based upon the Colegrove rationale. See Carpeneti, Legislative Apportionment: Multimember Districts and Fair Representation, 120 U. PA. L. REv. 666, 666 n.1 (1972) (analyzing pre-Baker redistricting litigation); Comment, supra note 3, at 191 n.46 (same).

In Gomillion v. Lightfoot, 364 U.S. 339 (1960), however, a unanimous Court found that an Alabama act changing the boundaries of the City of Tuskegee from a square to an "uncouth twenty-eight-sided figure," id. at 340 , was violative of the fifteenth amendment if its effect was to deprive blacks of their right to vote. See id. at 347-48. Though Justice Frankfurter distinguished the fifteenth amendment analysis in Gomillion from Colegrove and its progeny, the Court had in effect treated a redistricting case as justiciable. See Comment, supra note 3, at 192 \& n.49.

114 L. Tribe, American Constitutional Law § 13-2, at 1063 (2d ed. 1988).

118 Baker, 369 U.S. at 226 (emphasis in original).

116372 U.S. 368 (1963). 
was unconstitutional. ${ }^{117}$ In prophetic language, Justice Douglas wrote that " $t]$ he conception of political equality from the Declaration of Independence, to Lincoln's Gettysburg Address, to the Fifteenth, Seventeenth, and Nineteenth Amendments can only mean one thing - one person, one vote."118

The Court's first explicit recognition of the principle of one person, one vote came in 1964. In Wesberry $v$. Sanders, ${ }^{118}$ the Court struck down a Georgia apportionment statute that had established a congressional district with two to three times the population of other districts in the state. ${ }^{120}$ Writing for the majority, Justice Black concluded that "construed in its historical context, the command of Art. 1, $\S 2$, that Representatives be chosen 'by the People of the several States' means that as nearly as is practicable one man's vote in a congressional election is to be worth as much as another's."121 The rule of one person, one vote was said to fulfill "[the] Constitution's plain objective of making equal representation for equal numbers of people the fundamental goal for the House of Representatives." ${ }^{22}$ Notably, the Court based its holding solely upon its article I, section 2 analysis; Justice Black never reached the plaintiffs' claims that the statute violated the fourteenth amendment. ${ }^{123}$

Four months after the Supreme Court decided Wesberry, the Court extended the rule of one person, one vote to the realm of state

117 See id. at 376-81.

118 Id. at 381; see also id. at 382 (Stewart, J., concurring) ("Within a given constituency, there can be room for but a single constitutional rule-one voter, one vote.")

118376 U.S. 1 (1964).

120 See id. at 2-4.

121 Wesberry, 376 U.S. at 7-8 (citations omitted). Justice Harlan, in dissent, found Justice Black's art. 1, $\S 2$ argument to be historically inaccurate. See id. at 24 (Harlan, J., dissenting). Justice Harlan argued that art. 1, § 2 was concerned with apportionment among states, rather than districting within the states. Districting within states was left to Congress, based in the powers granted to it by art. 1, $\$ 4$. See id. at 34; see also L. TRIBE, supra note 114, at $\S 13-3.1064$ n.8 (noting that Justice Black's argument is unconvincing in light of the evidence presented by Justice Harlan); Auerbach, supra note 9, at 5 (finding Justice Harlan's argument to be "persuasive"); Kelly, Clio and the Court: An Illicit Love Affair, 1965 SuP. CT. REv. 119, 135 ("To put the matter bluntly, Mr. Justice Black, in order to prove his point, mangled constitutional history.").

122 Wesberry, 376 U.S. at 18.

${ }^{123}$ See id. at 8 n.10. Many commentators have criticized the Wesberry decision for not deciding the case on equal protection grounds. See, e.g., Auerbach, supra note 9, at 5 (characterizing Justice Black's reliance upon art. $1, \S 2$ of the Constitution to be "surprising" in light of the fact that the plaintiffs and Solicitor General as amicus curiae had put forth an equal protection claim); Note, Beyond Wesberry: State Apportionment and Equal Protection, 39 N.Y.U. L. REv. 264, 265 (1964) (arguing that in delimiting its decision to art. $1, \S 2$ grounds, the Court failed to establish controlling principles for state legislative redistricting cases). 
legislative redistricting in Reynolds and its companion cases. ${ }^{124}$ In Reynolds, the Court held that Alabama's apportionment scheme violated the equal protection clause. Writing for the majority, Chief Justice Warren stated that as "a basic constitutional standard," both houses of a bicameral state legislature must be redistricted on the basis of population in order to comport with the equal protection clause. ${ }^{125}$ One person, one vote was a necessary rule; otherwise, "an individual's right to vote for state legislators [would be] unconstitutionally impaired when its weight is . . . diluted when compared with votes of citizens living in other parts of the State." ${ }^{126}$

\section{Qualitative Dimensions}

Though Wesberry and Reynolds were clear in their requirement of population equality, they did little to specify the precise parameters of the rule. The Court clarified the standard, however, in Swann v. Ad$a m s,{ }^{127}$ stating that no deviation from strict population equality was allowable unless it was unavoidably "de minimis," or justified by "a satisfactory explanation grounded on acceptable state policy."128

In Kirkpatrick v. Preisler, ${ }^{129}$ the Court tightened the standard further by striking down a Missouri redistricting plan that varied only $1.6 \%$ from mathematical equality. ${ }^{130}$ Justice Brennan's statement that "the command of Art. I, $\S 2, \ldots$ permits only the limited population variances which are unavoidable despite a good faith effort to achieve

124 See Reynolds v. Sims, 377 U.S. 533 (1964). The companion cases to Reynolds all received full opinions. See Lucas v. Forty-Fourth Colorado General Assembly, 377 U.S. 713 (1964) (invalidating Colorado's legislative districting scheme); Roman v. Sincock, 377 U.S. 695 (1964) (invalidating Delaware's legislative districting scheme); Davis v. Mann, 377 U.S. 678 (1964) (invalidating Virginia's legislative districting scheme); Maryland Comm. for Fair Representation v. Tawes, 377 U.S. 656 (1964) (invalidating Maryland's legislative districting scheme); WMCA, Inc. v. Lomenzo, 377 U.S. 633 (1964) (invalidating New York's legislative districting scheme).

125 See Reynolds, 377 U.S. at 568. The Reynolds Court rejected any analogy between state legislative districting schemes and the federal legislative structure, stating that "in establishing our type of federalism a group of formerly independent States bound themselves together under one national government. . . . Political subdivisions of States-counties, cities, or whatever-never were and never have been considered as sovereign entities." Id. at 574-75. In two companion cases to Reynolds, the Court specifically invalidated state legislative schemes modeled after the federal system. See Lucas, 377 U.S. at 724-26, 738 \& nn.31-32; Maryland Comm. for Fair Representation,

377 U.S. at $671-72,675$ \& n.21.

${ }^{128}$ Reynolds, 377 U.S. at 568.

127385 U.S. 440 (1967).

128 Id. at 444 (emphasis in original).

129394 U.S. 526 (1969).

130 See id. at 529 n.1. The largest deviation from the ideal was $3.13 \%$, while the ratio of the largest to the smallest district was 1.06 to 1 . 
absolute equality, or for which justification is shown,"131 effectively withdrew the de minimis standard endorsed only two years earlier in Swann. ${ }^{132}$ In no case was this more evident than in Karcher v. Daggett, ${ }^{133}$ where the Court invalidated a New Jersey congressional redistricting plan that varied only $0.6984 \%$ from mathematical equality. ${ }^{134}$

The Court was less stringent in the realm of state legislative redistricting. In Mahan v. Howell, ${ }^{\mathbf{1 3 5}}$ the Court concluded that the standard of mathematical equality required by the equal protection clause was less stringent than the standard required for congressional redistricting under article I, section $2 .{ }^{136}$ The Court held that de minimis deviations from population equality can be justified by legitimate state policies applied in a consistent and nondiscriminatory fashion. ${ }^{137}$ Since Mahan, the Court has continued to apply this more lenient standard in state legislative redistricting cases. ${ }^{138}$

\section{B. "Critical Features" of Malapportionment Leading to Judicial Intervention}

One commentator has noted that the redistricting cases involved rights that were essential to the democratic process, and whose dimensions could not safely be left to elected representatives, who had a vested interest in the status quo. ${ }^{138}$ This Comment argues much the same principles, setting out two "critical features" in the districting realm that compelled judicial intervention.

131 Id. at 531. Justice Brennan went on to note that the Missouri legislature had rejected, without consideration, a plan which would have markedly reduced population variances among the districts. See id. at 532.

132 See L. TRIBE, supra note 114 , at $\S 13-5,1070$.

133462 U.S. 725 (1983).

134 See id. at 727-28. The Karcher Court also rejected the proposition that population deviances would be per se valid if less than the known statistical imprecision of available census data. See id. at 735 .

135410 U.S. 315 (1973).

${ }^{138}$ See id. at 322.

${ }^{137}$ See id. at 324-25.

138 See, e.g., Brown v. Thomson, 462 U.S. 835, 848-49 (1983) (O'Connor, concurring) (upholding a Wyoming state legislative redistricting plan with a population variance of $89 \%$ between the largest and smallest districts, on the grounds that Wyoming's "longstanding policy of preserving county boundaries" was legitimate); Gaffney v. Cummings, 412 U.S. 735, 737, 740-41 (1973) (upholding a Connecticut state legislative districting plan with deviations between districts of up to $7.83 \%$, finding them not sufficient to support a prima facie case of invidious discrimination). But see Board of Estimate v. Morris, 109 S. Ct. 1433, 1438-43 (1989) (holding a deviation of $78 \%$ among the New York City Board of Estimates to be inconsistent with the rule of one person, one vote).

138 See J. Ely, Democracy and Distrust 117 (1980). 


\section{Increasing Scope of Malapportionment}

Malapportionment in the United States, at both the congressional and state district levels, grew increasingly severe during the early 1960s. The 1950s had witnessed enormous shifts of population both within and among the states: sixteen states lost between one and three seats in Congress, while nine others gained up to eight seats. ${ }^{140} \mathrm{Al}$ though states that redistricted after the 1960 census more closely approximated population equality, those that did not manifested substantial inequalities in district populations and exhibited distinct urbanrural patterns. ${ }^{141}$ These factors contributed to a considerable overall dilution of metropolitan strength in most states and in the House of Representatives as a whole. ${ }^{\mathbf{1 4 2}}$

At the state level, both restrictive constitutional provisions conditioning representation of counties or other subunits on factors other than population and legislative failure to redistrict ensured that urban and suburban areas similarly were grossly underrepresented. ${ }^{143}$ Only six states were districted so that a minimum of forty percent of the state's population was needed to elect a majority in each house of the legislature, while in thirteen states, one-third or less of the population could elect majorities in both houses. ${ }^{144}$ Thus, over the course of the twentieth century, increasing population growth and the constant fluidity of the population's composition and location greatly exacerbated district malapportionment. ${ }^{\mathbf{1 4 5}}$

An important consideration that underlay the Court's arrival at the principle of one person, one vote was the fact that it was the only judicially manageable standard capable of resolving the increasingly se(1966).

140 See G. Baker, The Reapportionment Revolution 72-73 \& Table 7

${ }^{141}$ See id. at 78 (describing the urban-rural pattern as the universal presence within a state of overpopulated typically urban or suburban districts and underpopulated typically rural or small-town districts).

${ }^{142}$ See id. Even states that had redistricted after the 1960 census often experienced dilution of metropolitan voting strength. For example, Arizona's First Congressional District, which encompassed the City of Phoenix, contained a population of 663,510, while the rural Third Congressional District had only 198,236 inhabitants. See id. at 73 (Table 7).

${ }_{143}$ See id. at 25 (citing population figures and relative representational power patterns within states from $1 P$. David \& R. EisenberG, Devaluation of THE URBAN AND SUBURBAN Vote 9 (1961)). It is true, however, that malapportionment was caused in some states by state constitutions that either required each county to be assured of at least one representative, or that no county should have more than one representative for each chamber. See R. McKaY, supra note 110, at 49.

144 See G. Baker, supra note 140, at 32 (citing figures set forth in National Municipal League, Compendium of Legislative ApPoRTionment (1962)).

145 See Auerbach, supra note 9, at 68. 
vere malapportionment problem. The bold action of mandating one person, one vote was, as one commentator noted, "an effort by the Court to solve a national problem which was assuming crisis proportions.... "148

The scheme of decennial redistricting urged by the Court in Reynolds was geared specifically at combining the requirement of mathematical equality with an automatic adjustment process, thus facilitating the goal of equal legislative representation notwithstanding the growth and fluidity of the nation's population. ${ }^{147}$ While not declaring decennial redistricting to be a constitutional requisite, the Reynolds Court urged that "compliance with such an approach would clearly meet the minimal requirements for maintaining a reasonably current scheme of legislative representation," and warned that "if reapportionment were accomplished with less frequency, it would assuredly be constitutionally suspect." 148

\section{Legislative Self-Interest in Resisting Districting Reform}

Political realities in the United States also frustrated malapportionment reform. In Baker, the Court noted that in the more than sixty years since the 1901 adoption of a previous districting scheme, all proposals for redistricting in both Houses of the General Assembly had failed. ${ }^{149}$ In simple terms, "[s]tate legislators who completely understood the growing disparities in population representation were also those who had the most to gain from not calling attention to the fact."150 Legislators at both the federal and state levels had derived their power from existing districting schemes and thus were loathe to threaten their political viability by tampering with the status quo. ${ }^{151}$ Political realities only perpetuated the malapportionment in the nation.

The Court's action in formulating the one person, one vote rule thus nullified the problem of the political intransigence that so characterized state legislative action in the redistricting context. As one com-

146 Id. at 70.

${ }^{147}$ See id. at $12,68-69$.

1 18 Reynolds, 377 U.S. at 583-84.

149 See Baker, 369 U.S. at 191 \& n.10.

160 R. McKay, supra note 110 , at 38 .

151 See, e.g., J. ELY, supra note 139, at 121 (stating that legislators had a selfinterest in "maintaining whatever apportionment . . . that got and keeps them where they are); R. McKAY, supra note 110, at 38 (noting that due to legislative self-interest in retaining the status quo, "the resulting conspiracy of silence was understandable"); L. TRIBE, supra note 114 , at $\S 13-3,1064$ n.9 (criticizing Justice Harlan's dissent in Wesberry for not addressing the probability that "legislators who had achieved their positions through malapportionment would be unlikely to remedy such electoral schemes"). 
mentator has noted:

[T] The essence of our constitutionalism [is] that 'all forms of organized power over men's wills should in some way be accountable to serve ends of broader concern than the purposes of power holders.' It is this constitutional ideal that is being violated by self-interested legislators when they refuse to reapportion equitably. Only the Court could vindicate it. ${ }^{\mathbf{1 5 2}}$

Absent action by the Court, the political realities that impeded districting reform would have continued to pervade the constitutional system.

\section{The Presence of "Critical Features" in the Realm of VOTER REgISTRATION}

This Comment has argued that the "critical features" in the electoral realm of a rapid and worsening condition over time and legislative self-interest in resisting reform compelled the Supreme Court to intervene in the "political thicket" of redistricting. Part III of this Comment demonstrates that these "critical features" similarly are present in the realm of voter registration. Part A demonstrates that registration is on a rapid, downward spiral in the United States. It then notes that poor, young, and minority citizens suffer most from these voting restrictions. Part B argues that legislative resistance to the reform of voter registration laws is rooted in the fear of redefining the contours of the electorate from which they were voted into office.

\section{A. The Downward Spiral of Voter Registration}

The presence of registration laws in the United States clearly presents significant barriers to the exercise of the franchise for many citizens. A more stark reality, however, is that the rate of registration in the United States is entrenched in a continuous downward spiral. And as voter registration drives generally have proved ineffectual at curbing the nonregistration spiral, ${ }^{153}$ these figures only show signs of mushrooming. ${ }^{154}$ In the 1988 general election, 91,602,291 Americans, or $50.16 \%$ of those eligible to vote, cast a ballot. ${ }^{155}$ Utilizing these

152 Auerbach, supra note 9, at 70 (quoting J. Hurst, Justice Holmes ON LEGAL HISTORY 29 (1964)).

${ }_{103}$ See, e.g., P. KIMBALI, supra note 18 , at 290-91 (noting that voter registration drives, despite some "spectacular successes," generally have not proven effectual).

154 See W. GROTTY, supra note 36, at 52 (predicting that there would be 122 million nonvoters in the United States by the year 2000).

1s5 See 50.16\% Voter Turnout Was Lowest Since 1924, supra note 10, at A36, col. 1. 
figures, a series of mathematical calculations finds that between $40-43 \%$ of all eligible Americans were not registered to vote on election day. ${ }^{156}$ In absolute terms as well, the numbers are striking-roughly seventyfive million Americans were not registered to vote on election day. ${ }^{157}$ If one presumes that the turnout rate will continue to fall, as it has done precipitously since $1960,{ }^{158}$ it is logical to presume further that there will be a corresponding decline in the registration rate. This downward spiral of registration could ultimately provoke a situation in which more than fifty percent of eligible American voters are not registered to vote, or in which more Americans were not registered than voted in a presidential election.

This spiral is especially extreme in its impact upon minorities, the young, and the urban poor. ${ }^{159}$ As the United States Commission on Civil Rights noted in 1981, "given the depressed economic status of many minority communities, restrictive registration practices are espe-

${ }^{156}$ These findings are based upon a number of basic cross-multiplication calculations. $91,602,291$ Americans voted in 1988, representing $50.16 \%$ of the eligible populace. See id. In the "percentage fraction" then, $50.16 \%$ would be the numerator (the percentage of citizens who actually voted in the 1988 election) and $100 \%$ would be the denominator (the percentage of citizens eligible to vote in the 1988 election). This fractional equation would be equal to the "real number fraction," which would have $91,602,291$ as the numerator (the number of citizens who actually voted in the 1988 election) and the unknown number of citizens eligible to vote in the 1988 election as the denominator. By multiplying the numerator of the "real number fraction" $(91,602,291)$ with the denominator of the "percentage fraction" $(100 \%)$, and then dividing the result by the numerator of the "percentage fraction" (50.16\%), one would find a "real number fraction" denominator of $182,620,197$ - the number of voters eligible to vote in the 1988 election.

Studies have demonstrated that somewhere between $85 \%$ and $88 \%$ of all registered voters do in fact vote. See supra note 109 and accompanying text. It therefore is possible to approximate closely the number of unregistered Americans by utilizing another series of cross-multiplication equations. Using the conservative estimate that $85 \%$ of registered Americans actually voted over $100 \%$, one would find that there were $107,767,401$ registered Americans and 74,852,706 nonregistered citizens on election day, the latter representing roughly $40 \%$ of the number of citizens eligible to vote. The more liberal estimate that $88 \%$ of registered voters did in fact vote finds that there were $104,935,125$ registered Americans on election day and 78,526,684 nonregistered citizens, the latter comprising roughly $43 \%$ of the eligible electorate.

157 See figures cited id.

158 See supra note 12 and accompanying text. As one commentator has noted, "[i]f qualifications remain as they are, there is no reason to believe that turnout will improve over the next several decades." W. CROTTY, supra note 36, at 52.

${ }_{168}$ See, e.g., W. Crotry, supra note 36, at 53-55 \& Table 2.1 (demonstrating that far fewer blacks and Hispanics register than do whites); P. KrmBaLL, supra note 18 , at 289 ("The phenomenon of nonparticipation exists throughout the country, but is most prevalent within those segments of the population most disconnected . . . [ $[$ ] urban poor, the young, Blacks, Mexican-Americans, the American Indian . . .); Williams \& Morris, Is the Electoral Process Stacked Against Minorities?, in Elections AMERICAN STYLE, supra note 24, at 139 (noting that registration requirements disproportionately disadvantage minorities). 
cially burdensome."160 Voter participation has always been strongly related with socioeconomic factors, especially education and income; as a result, minority groups and the poor have experienced lower rates of participation. ${ }^{\mathbf{1 6 1}}$ This problem is exacerbated by a younger population, notorious for their low levels of participation, in urban minority communities. ${ }^{162}$ Thus, minorities and the poor, who have in effect have "the largest stake in social change," remain disproportionately disconnected from the political process. ${ }^{163}$ The inherent defects in American registration laws have culminated in a "critical point" for these groups, ${ }^{184}$ in which the right to vote often is no longer a fundamental right of citizenship.

\section{B. Legislative Self-Interest in Resisting Registration Reform}

Political realities also dictate that judicial action be taken in the realm of registration. Many legislators at both the federal and state level have derived their power from existing levels of citizen participation, and may be loathe to change the status quo and thereby threaten their political future. ${ }^{\mathbf{1 6 5}}$ As one set of commentators has noted:

Both Congress and the state legislatures - and, in fact, most practicing politicians - fear the impact of drastic registration changes that would redefine the electorate by substantially increasing its numbers. Politicians are content to maintain an electorate they understand and with which they have had success. Self-interest favors retention of the familiar and

160 UNited States Commission on Givil Rights, supra note 96, at 66. Lani Guinier specifically has noted that registration requirements discriminate, as "private resources such as cars and telephones, which are critical to functioning in this two-step process, are unavailable to poor people, especially racial and language minorities." Guinier, supra note 24, at 419.

${ }_{161}$ See, e.g., W. CROTTY, supra note 36 , at 53 (noting that "[t]he young, blacks, the least educated, the unemployed, blue collar workers . . . are the people least likely to be part of the electorate"); P. KIMBALL, supra note 18, at 16-17 ("Voter participation has always exhibited a high correlation with education and income, two spheres of urban disadvantage.").

${ }^{162}$ See P. Krmball, supra note 18, at 16-17.

${ }_{103}$ Id. at 289; see Grotty, supra note 11 , at $77-78$ (noting that "those left out of the active electorate are the ones least able to afford it").

164 Report: AfTer THE Voting Rights ACT, supra note 79, at 6.

${ }^{106}$ See Crotty, Introduction: Political Reform in the Late Twentieth Century, in Paths to Political Reform, supra note 11, at xviii ("Many elective office holders fear the redefinition through registration reform of an electorate with which they now feel comfortable."); see also Fitts, The Vices of Virtue: A Political Party Perspective on Civic Virtue Reforms of the Legislative Process, 136 U. PA. L. REv. 1567, 1573 \& n.13 (1988) (detailing legal scholarship which argues that legislators often act in their own self-interest, rather than attempt to further the public interest). 
the safe. ${ }^{186}$

One reason for the resistance to registration reform has been opposition by Republican and southern Democratic legislators who fear an increase in the "liberal" electorate. ${ }^{167}$ Most social scientists believe, however, that the increase in participation through registration reform would generally be insensitive to partisan dynamics. ${ }^{168}$

Presently, there are eight bills before Congress that aim to reform the system of personal registration through various means. ${ }^{169}$ Some of

166 W. Crotty \& G. Jacobsen, American Parties in Decline 19 (1980). 37.

${ }^{167}$ See Crotty, supra note 11, at 78; Rosenstone \& Wolfinger, supra note 18 , at

168 See, e.g., Converse, The Concept of a Normal Vote, in A. CAMPBEL., P. Converse, W. Miller \& D. Stokes, Elections and the Political Order 29 (1966) (noting the "general insensitivity of partisanship to large changes in turnout"); Crotty, supra note 11, at 78 (noting that "[m]ost nonvoters are too apolitical to swell the ranks of liberals or Democrats, as many contend they would. . . . The majority of nonvoters are open to persuasion by either party; they are tied to neither"); Rosenstone \& Wolfinger, supra note 18, at 38 ("[T]he expanded electorate produced by relaxing registration laws would be remarkably similar to the smaller, actual electorate."); Squire, Wolfinger \& Glass, supra note 11, at 61 (determining through statistical analysis that the changes in partisan and ideological identification as a result of registration reform would not be statistically significant).

A New York Times/CBS Poll conducted after the 1988 general election supported these arguments, finding that if the election had had a turnout of $100 \%$, George Bush's victory margin would have been even greater than it was in the actual election. See If Nonvoters Had Voted: Same Winner, But Bigger, supra note 100, at B16, col. 3.

${ }^{169}$ See S. 874, 101st Cong., 1st Sess. (1989) ("National Voter Registration Act of 1989") (introduced by Senator Ford) (establishing national voter registration procedures for presidential and congressional elections); S. 675, 101st Cong., 1st Sess. (1989) ("Equal Access to Voting Act of 1989") (introduced by Senator Cranston) (eliminating discriminatory barriers to voter registration); H.R. 2811, 101st Cong., 1st Sess. (1989) ("Postal Service Voter Registration Facilitation Acts of 1989) (introduced by Representative Leland) (providing space in post offices for state registration authorities to place voter registration forms); H.R. 2810, 101st Cong., 1st Sess. (1989) ("Postal Service Voter Registration Facilitation Acts of 1989) (introduced by Representative Leland) (providing that the Postal Service give voter registration forms along with change-of-address forms); H.R. 2190, 101st Cong., 1st Sess. (1989) (introduced by Speaker Foley) (establishing national voter registration procedures for elections for federal office); H.R. 983, 101st Cong., 1st Sess. (1989) ("Jury Selection and Voter Participation Act of 1989") (introduced by Representative McMillen) (amending title 28, U.S.C., to provide that grand and petit juries be selected from sources other than voter registration lists); H.R. 17, 101st Cong., 1st Sess. (1989) ("Universal Voter Registration Act of 1989") (introduced by Representative Conyers) (establishing national voter registration procedures for elections for federal office); H.R. 15, 101st Cong., 1st Sess. (1989) ("National Voter Registration Act of 1989") (introduced by Representative Swift) (same). One other bill, introduced by Senator Moynihan, S. 214, would have the Department of Health and Human Services establish a counterfeit-free Social Security card that could eventually be used as a voter registration card. See S. 214, 101st Cong., 1st Sess. (1989).

The presentation of these differing bills should not be interpreted as an assertion that they are identical, or equally progressive in terms of registration reform. It is beyond the scope of this Comment, however, to put forth an in-depth analysis of provi- 
the bills are "incrementalist" reforms, representing modest plans aimed at requiring or persuading states to incorporate changes into electoral procedures in order to increase registration, while others are "bigbang" proposals, aimed at fundamentally altering traditional registration practices. ${ }^{170}$ It is likely, however, based upon the fate of similar bills, that to the extent these proposals contemplate significant reform of the registration process consistent with universal enrollment, none will be passed, let alone reach the House or Senate floor. Congress recently has rejected or failed to act upon numerous bills that have attempted to remedy defects in the system of personal registration. ${ }^{171}$ In fact, congressional attempts to reform the registration process have been resisted since the early 1970 s. $^{172}$ Furthermore, as the legislative process

sions of the various bills.

170 See Crotty, supra note 11 , at $97-98$.

171 In addition to the bills presently before the 101st Congress, see supra note 169 and accompanying text, a number of similar bills have been introduced in the previous two Congresses, all failing to reach the floor of the House or Senate. See, e.g., S. 2061, 100th Cong., 2d Sess. (1988) ("Universal Voter Registration Act of 1988") (establishing national standards for elections for federal office); H.R. 3950, 100th Cong., 2d Sess. (1988) ("Universal Voter Registration Act of 1988") (same); S. 1888, 100th Cong., 1st Sess. (1987) ("Universal Voter Registration Act of 1987") (same); S. 1405, 100th Cong., 1st Sess. (1987) ("Voter Registration Act of 1987") (amending title 39, U.S.C., to provide that change-of-address forms submitted to the Postal Service be furnished to the appropriate state authority for voter registration purposes); H.R. 3666, 100th Cong., 1st Sess. (1987) ("Universal Voter Registration Act of 1987") (establishing national standards for voter registration); H.R. 3023, 100th Cong., 1st Sess. (1987) ("Voter Participation Act of 1987) (providing for election day and mail registration for federal elections); H.R. 2750, 100th Cong., 1st Sess. (1987) ("Voter Registration Act") (amending title 39, U.S.C., to provide that change-of-address forms submitted to the Postal Service be furnished to the appropriate state authority for voter registration purposes); S. 1439, 99th Cong., 1st Sess. (1985) ("Voter Registration Act of 1985") (same); S. 1420, 99th Cong., 1st Sess. (1985) ("Postage Free Election Material") (amending title 39, U.S.C., to provide that voter registration forms, among others, be mailed by election authorities free of postage); H.R. 2216, 99th Cong., 1st Sess. (1985) ("Free Postage Election Participation Act") (amending title 39, U.S.C., to provide that voter registration forms, among others, be mailed by election agencies free of postage); H.R. 1668, 99th Cong., 1st Sess. (1985) ("Voter Registration Act of 1985") (amending title 39, U.S.C., to provide that change-of-address forms submitted to the Postal Service be furnished to the appropriate state authority for voter registration purposes); H.R. 1454, 99th Cong., 1st Sess. (1985) ("Registration Deadline Elimination Act of 1985") (protecting the voting rights guaranteed by the fourteenth and fifteenth amendments by preventing inappropriate registration procedures); H.R. 1453, 99th Cong., 1st Sess. (1985) ("Postcard Registration Act of 1985) (protecting voting rights by eliminating certain barriers to participation in federal elections).

${ }^{172}$ In the early through mid 1970 s, there also were numerous bills aimed at reforming the registration process that either went down to defeat or were not acted upon. For a mere sampling of the numerous bills that were so proposed, see, e.g., S. 1072, 95th Cong., 1st Sess. (1977) ("Universal Voter Registration Act of 1977") (establishing a universal voter registration program); H.R. 5400, 95th Cong., 1st Sess. (1977) ("Universal Voter Registration Act of 1977") (same); H.R. 11552, 94th Cong., 2d Sess. (1976) ("Voter Registration Act") (establishing a Voter Registration Administration in the Federal Election Commission for purposes of administering a voter regis- 
tration program through the Postal Service); S. 1177 94th Cong. 1st Sess. (1975) ("Voter Registration Act") (amending title 13, U.S.C., to establish within the Census Bureau a Voter Registration Administration for the purpose of administering a voter registration program through the Postal Service); H.R. 6079, 94th Cong., 1st Sess. (1975) ("States Voter Registration Act") (amending the Federal Election Commission Act of 1971 to establish within the Federal Election Commission a Voter Registration Bureau for the purpose of assisting states in improving voter registration programs); H.R. 4093, 94th Cong., 1st Sess. (1975) ("Voter Registration Act") (amending title 13, U.S.C., to establish within the Census Bureau a Voter Registration Administration for the purposes of administering a national voter registration program through the Postal Service); H.R. 1686, 94th Cong., 1st Sess. (1975) ("Voter Registration Act") (establishing a Voter Registration Administration in the General Accounting Office for purposes of administering a voter registration program through the Postal Service); S. 472, 93d Cong., 1st Sess. (1973) ("Voter Registration Assistance Act of 1973") (amending title 13, U.S.C., to establish a Voter Registration Administration in the Census Bureau to carry out a program of financial assistance to the states to encourage and assist voter registration); S. 352, 93d Cong., 1st Sess. (1973) ("Voter Registration Act") (amending title 13, U.S.C., to establish a Voter Registration Administration in the Census Bureau for the purposes of administering a voter registration program through the Postal Service); H.R. 8053, 93d Cong., 1st Sess. (1973) ("Voter Registration Act") (same); H.R. 4846, 93d Cong., 1st Sess. (1973) ("National Registration Rights Act of 1973") (amending the Voting Rights Act of 1965 to safeguard the constitutional and civil liberties of American citizens with regard to lawful guarantees of participation in the democratic process); H.R. 580, 93d Cong., 1st Sess. (1973) ("Voter Registration Act") (amending title 13, U.S.C., to establish within the Census Bureau a National Voter Registration Administration for the purpose of administering a voter registration program through the Postal Service); S. 3420, 92d Cong., 2d Sess. (1972) ("Voter Registration Assistance Act of 1972") (amending title 13, U.S.C., to establish a Voter Registration Administration in the Census Bureau to carry out a program of financial assistance to the states to encourage and assist voter registration); S. 2574, 92d Cong., 1st Sess. (1971) ("National Voter Registration Act") (amending title 13, U.S.C., to establish in the Census Bureau a National Voter Registration Administration for purposes of a voter registration program through the mail); S. 2457, 92d Cong., 1st Sess. (1971) ("Universal Voter Registration Act of 1971") (establishing a system of universal voter registration for federal elections); S. 2445, 92d Cong., 1st Sess. (1971) ("National Federal Voter Registration Act of 1971") (providing for nationwide registration of voters for federal offices); S. 1199, 92d Cong., 1st Sess. (1971) ("Universal Enrollment Act of 1971") (amending title 13, U.S.C., for Census Bureau to undertake a quadrennial enrollment of voters for presidential elections who meet all state qualifications except residency); H.R. 12016, 92d Cong., 1st Sess. (1971) ("Canvass of the Election Process") (amending title 13, U.S.C., to have Census Bureau establish a program of electoral canvassing); H.R. 10442, 92d Cong., 1st Sess. (1971) ("Voting Rights Act Amendments of 1971") (establishing a system of automatic voter registration); H.R. 6088, 92d Cong., 1st Sess. (1971) ("Universal Enrollment Act of 1971") (amending title 13, U.S.C., for Census Bureau to undertake a quadrennial enrollment of voters for presidential elections who meet all state qualifications except residency); S. 4238, 91st Cong., 2d Sess. (1970) ("Universal Enrollment Act of 1970") (amending title 13, U.S.G., by authorizing the Secretary of Commerce through the Census Bureau to undertake a quadrennial enrollment of those persons that meet the qualifications of the various states other than residency for presidential elections); H.R. 19010, 91st Cong., 2d Sess. (1970) ("Universal Enrollment Act of 1970") (same).

Of these proposals, a bill proposed by Senator Gale McGee of Wyoming came the closest to passage. That bill, S. 2574 was reported favorably out of committee in 1972 but failed to win passage in the Senate by a 46-42 vote. See 118 Cong. REc. 8450 (1972). Its successor bill, S. 352, won passage in the Senate by a 57-37 vote in 1973, see 119 Cong. REC. 14,877 (1973), but lost in the House on a procedural vote by seven 
inherently favors incremental rather than broad-scale reform, ${ }^{173}$ even if reform legislation were to be passed, it would not likely achieve anything of fundamental consequence. ${ }^{174}$

This is not to say that all or even most legislators who oppose registration reform do so consciously for these reasons. Instead, it is simply enough, as the Court implied when faced with malapportionment in Baker $v$. Carr, ${ }^{175}$ that a worsening electoral infirmity is present, that viable reform proposals have been put forth, and that legislators have a self-interest in resisting these reforms. ${ }^{178}$ Judicial intervention thus is appropriate in the registration realm due to legislative inaction at both the federal and state levels in reforming voter registration laws.

\section{Judicial Intervention in the Realm of Voter REGISTRATION}

The diminishing numbers of eligible citizens who register and vote in the United States portends danger. As one commentator has noted bluntly, "[t]he foundations of the American government do appear in some jeopardy. People are participating less in the most basic form of political involvement, voting. This development cannot be a healthy sign for a governing system that depends on the support of its citizenry." 177 Part IV of this Comment argues that absent registration reform, the Supreme Court soon will be forced to remedy the system of personal registration in the United States. Part A sets out potential constitutional challenges to registration laws that would serve as the basis for judicial intervention. Part B then argues that the Court must mandate that the state undertake the responsibility for the uniform enrollment of voters at regular intervals in order to remedy the "critical features" that characterize registration laws.

\footnotetext{
votes in 1974. See K. Phillips \& P. Blackman, supra note 24, at 61.

${ }^{173}$ See Crotty, supra note 11 , at 100.

174 See Crotty, supra note 165 , at xviii.

175369 U.S. 186 (1962).

176 In Baker, the Court simply noted that all proposals for redistricting reform had been defeated by the Tennessee General Assembly. See id. at 191 \& n.10. In making this notation, however, the Court implied that state legislators could not be trusted to bring the state's districting scheme into conformity with the Constitution. This distrust stemmed from the Court's recognition of legislative self-interest in impeding districting reform. See supra notes 149-52 and accompanying text.

${ }^{177}$ Crotty, supra note 11, at 67; see P. Kimball, supra note 18 , at 289 ("The moral legitimacy of government is weakened when so many in nominal control of a system of self-government are so obviously not involved in its electoral rituals.").
} 


\section{A. Potential Constitutional Challenges to Registration Laws}

States are empowered under the Constitution to establish reasonable voter qualifications, ${ }^{178}$ and to set "[ $t$ ]he Times, Places, and Manner of holding Elections for Senators and Representatives."178 Consequently, the Supreme Court has upheld some restrictions of the right to vote, such as minimum age, ${ }^{180}$ citizenship, ${ }^{181}$ and residency requirements. ${ }^{182}$ The Court also has implicitly recognized registration restrictions to be legitimate limitations on the right to vote. In Anderson $v$. Celebrezze, ${ }^{183}$ the Court noted:

We have recognized that, 'as a practical matter, there must be a substantial regulation of elections if they are to be fair and honest and if some sort of order, rather than chaos, is to accompany the democratic processes.' To achieve these necessary objectives, States have enacted comprehensive and sometimes complex election codes. Each provision of these schemes, whether it governs the registration and qualifications of voters . . . inevitably affects-at least to some degree-the individual's right to vote and his right to associate with others for political ends. Nevertheless, the State's important regulatory interests are generally sufficient to justify reasonable, nondiscriminatory restrictions. ${ }^{184}$

The Court thus found in Anderson that some voting restrictions that

${ }^{178}$ Article I, Section 2 reads: "The House of Representatives shall be composed of Members chosen every second Year by the People of the several States, and the Electors in each State shall have the Qualifications requisite for Electors of the most numerous Branch of the State Legislature." U.S. ConsT. art. I, § 2, cl. 1.

179 U.S. ConST. art. $1, \S 4$, cl. 1 . In fact, the states could choose to fill public offices by appointment if they so desired. See Rodriguez v. Popular Democratic Party, 457 U.S. 1, 8-12 (1982).

${ }_{180}$ See Oregon v. Mitchell, 400 U.S. 112, 124-31 (1970). In Mitchell, though upholding congressional power to lower the minimum age of voters in federal elections from 21 to 18, the Court upheld the power of states to set minimum age requirements in state and local elections. The twenty-sixth amendment, adopted after the Court's holding in Mitchell, now guarantees that "[t]he right of citizens of the United States, who are eighteen years of age or older, to vote shall not be denied or abridged by the United States or by any State on account of age." U.S. CONST. amend. XXVI, $\S 1$. However, Mitchell still stands for the proposition that states have the power to set minimum age requirements for voting, so long as such requirements fall within the strictures of the twenty-sixth amendment.

${ }_{181}$ See Holt Givic Club v. Tuscaloosa, 439 U.S. 60, 68-70 (1978).

182 See Marston v. Lewis, 410 U.S. 679, 681 (1973); Burns v. Fortson, 410 U.S. 686, 686-87 (1973).

18s 460 U.S. 780 (1983).

${ }^{184}$ Id. at 788 (emphasis added) (quoting Storer v. Brown, 415 U.S. 724, 730 (1974)). 
burden the right to vote are not subject to strict scrutiny, noting instead that courts should balance the "character and magnitude of the asserted injury" with the "precise interests" put forth by the states to justify the restriction. ${ }^{185}$

Lower courts similarly have been loathe to apply strict scrutiny when registration laws are challenged absent an absolute deprivation of the right to vote. Indeed, in Coalition for Sensible \& Humane Solutions $v$. Wamser, ${ }^{186}$ a district court held that absent absolute preclusion from voting, the applicable standard of review for registration restrictions was rationality. ${ }^{187}$ Applying that standard, the court found that St. Louis's refusal to deputize volunteers as voter registrars was rationally related to the city's interest in preventing fraud and maintaining impartiality. ${ }^{\mathbf{1 8 8}}$

Several credible arguments have been put forth, however, that demonstrate that contemporary registration laws could be subject to successful constitutional challenges. ${ }^{189}$ Such a legal challenge to registration laws could serve as the underlying basis for judicial intervention in the voter registration realm. In the case of redistricting, it was an equal protection challenge to Tennessee's districting laws in Baker $v$. Carr $^{180}$ that opened the door for the Court's mandating of the rule of one person, one vote. A constitutional challenge to registration laws could serve much the same purpose.

One set of promising constitutional challenges ${ }^{191}$ is premised upon

${ }^{185}$ See id. at 789; see also 2 R. Rotunda, J. Nowak \& J. Young, Treatise on Constitutional Law: Substance AND Procedure $\S \S 18.31$ (a)-18.36 (1986) (noting that the Court has never held that all restrictions of voting would be subject to the traditional strict scrutiny standard).

${ }_{186} 590$ F. Supp. 217 (E.D. Mo. 1984), affd, 771 F.2d 395 (8th Cir. 1985).

${ }^{187}$ See id. at 222-23. But see Note, Voter Registration, supra note 25, at 1629-30 (arguing that the Wamser court misinterpreted McDonald v. Board of Election Comm'rs, 394 U.S. 802 (1969) by citing it for the proposition that the rationality standard is applicable absent a total deprivation of the right to vote).

${ }_{188}$ See Wamser, 590 F. Supp. at 222; see also Edwards v. Austin, No. 84-CV8347-FL (E.D. Mich. Sept. 26, 1984) (mem.) (rejecting a challenge to Michigan registration practices, finding that there is no constitutional right to be a deputy registrar). But see Rhode Island Minority Caucus, Inc. v. Baronian, 590 F.2d 372, 376 (1st Cir. 1979) (though upholding denial of plaintiffs' motion for a preliminary injunction as moot in that election had passed, stating that plaintiffs' challenges to their exclusion by Providence's Board of Canvassers as voter registrars appear to state sufficient equal protection injury and substantial first amendment questions if tried on the merits); Iowa Socialist Party v. Slockett, 604 F. Supp. 1391, 1397-98 (S.D. Iowa 1985) (finding state procedure limiting the appointment of mobile deputy registrars to those nominated by county chairmen of the two largest political parties to be unconstitutional).

189 See sources cited supra notes 25.

190.369 U.S. 186 (1962).

181 It is beyond the scope of this Comment to present an analytical overview of the potential constitutional challenges to registration laws that previously have been set 
the fundamental right to vote. ${ }^{192}$ It would argue that registration restrictions violate the equal protection clause by not being a sufficient "compelling state interest" nor the "least restrictive means" of achieving such an interest. ${ }^{193}$ In terms of the former, the limits on the hours and locations of registration sites based upon an economic rationale could be challenged as an insufficient justification when the opportunity for citizens to register is thereby impeded. ${ }^{194}$ It also could be argued that though the prevention of vote fraud is a compelling state interest, most states do not utilize pre-election day fraud detection methods that would justify the resulting hindrance on registration. ${ }^{195}$ Finally, it could be demonstrated that there are alternative methods of registration that prevent vote fraud yet are "less restrictive" in the burden that is placed on the potential registrant. ${ }^{196}$ These are among the myriad of potential constitutional arguments that could serve as the linchpin for judicial intervention in the voter registration -realm.

\section{B. Remedy of Governmental Voter Enrollment}

In order to remedy satisfactorily the "critical features" that characterize the system of personal registration in the United States, ${ }^{197}$ as well as satisfy the equal protection provisions that these laws violate, the Court will be compelled to mandate uniform voter enrollment by the government. In other words, the Court must transfer the onus of registration from the individual to the state.

In the case of redistricting, a clear result of the rule of one person, one vote was that it served to remedy the "critical features" that char-

forth. For a detailed dissemination of these arguments, see the sources cited supra note 25.

192 See Reynolds v. Sims, 377 U.S. 533, 561-62 (1964).

183 See, e.g., Comment, supra note 25, at 502-05; Note, Voter Registration, supra note 25 , at $1633-40$.

184 See Comment, supra note 25, at 503. In Bishop v. Lorenzo, 350 F. Supp. 576 (E.D.N.Y. 1972), a federal district court agreed with this argument, finding that "[w]hen [the right to vote] is weighed in the balance against clerical inconvenience, the latter must give way. The state may not deny a voter the right to register (and hence to vote) because of clerical deficiencies. . . . The remedy lies in providing more clerks rather than registering fewer voters." Id. at 587.

This argument could be extended as well to cases in which registrars refuse to deputize others as registrars. This argument, however, has not yet been successful in the lower courts. See supra note 188 and accompanying text.

195 See Note, Voter Registration, supra note 25, at 1633-35. In practice, no state regularly checks its registration records against those of other states, see id. at 1634 \& n.95, and many states do not require identification upon registering. See id. at $1634 \&$ n.98.

186 See id. at $1635-40$.

197 See supra notes 153-76 and accompanying text. 
acterized malapportionment in the United States. ${ }^{198}$ In implicitly requiring states to redistrict every ten years, ${ }^{109}$ the Court both erased the problem of legislative self-interest in resisting reform and guaranteed that the requirement of mathematical equality would be combined with an automatic, decennial adjustment process. ${ }^{200}$ Any other remedy which did not require an automatic adjustment process would have only temporarily remedied the "critical features"; malapportionment would have grown again and legislators would have remained loathe to reform districting laws.

In the realm of voter registration, the only judicial mandate that would remedy the inherent "critical features" would be a requirement that the government undertake the responsibility of uniform voter enrollment at regular intervals. "Incrementalist" remedies" the good will and self-motivation of the state or other electoral unit. ... [w]ith no pressure [to act affirmatively,] . . . reform is unlikely."202 From their disenfranchising origins ${ }^{203}$ to their present status, ${ }^{204}$ registration laws increasingly serve to restrict qualified citizens from the ballot; piecemeal reforms aimed at encouraging citizens to register cannot overcome these historical burdens. Studies have demonstrated that registration drives generally are ineffective at curbing the downward spiral of registration, ${ }^{205}$ and there is evidence that even in the one state that does not require registration, North Dakota, ${ }^{208}$ the historical impact of registration laws impedes many citizens from the ballot. ${ }^{207}$ Any remedy that retains the present situation in which the burden of registration is placed upon the individual cannot ensure the downward spiral of registration rates will cease.

The Court thus will be compelled to mandate that the state undertake uniform voter enrollment at regular intervals. While there are a number of "big-bang" proposals ${ }^{208}$ for registration reform that already

188 For an analysis of these "critical features," see supra notes $140-52$ and accompanying text.

189 See Reynolds v. Sims, 377 U.S. 533, 583-84 (1964).

200 See supra note 147 and accompanying text; text accompanying note 152.

201 See text accompanying note 170 for a brief description of "incrementalist" remedies.

202 Crotty, supra note 11 , at 97.

${ }^{203}$ See supra notes $26-73$ and accompanying text.

204 See supra notes 78-100 and accompanying text.

${ }^{205}$ See supra note 153.

${ }^{208}$ See supra note 74 and accompanying text.

207 One-third of the nonvoters in North Dakota stated that they did not vote in the 1980 general election because they were not registered. See Glass, Squire \& Wolfinger, supra note 24 , at 53 .

${ }^{208}$ See text accompanying note 170 for a brief description of "big-bang" remedies. 
have been put forth, ${ }^{208}$ it would be for the states to develop and implement programs that comport with the new constitutional mandate.

\section{GoNCLUSION}

Registration laws in the United States have had an inherent and continuing disenfranchising effect. The resulting impediment to the ballot for millions of qualified citizens threatens the very legitimacy of democratic government. ${ }^{210}$ As one commentator has noted, "[d]emocracy must be its own teacher. Those whose lives are untouched by any sort of involvement have no framework of experience within which to develop the patience and appreciation for the complexities or tradeoffs of evolutionary progress."211

This Comment has argued that the increasingly worsening condition of the system of voter registration will, absent imminent legislative reform, compel judicial intention similar to the affirmative action taken by the Court when confronted with gross malapportionment. Faced with the presence of downwardly spiralling registration rates and legislative self-interest in resisting registration reform, the Court will be forced to require the states to undertake the responsibility of the uniform enrollment of citizens at regular intervals. This constitutional mandate will not by itself induce a turnout in the United States comparable to those of other western nations, nor serve as a panacea for the apathy and alienation that many citizens feel from the political process. It will ensure, however, that the fundamental right to vote will no longer be predicated upon obscure, complex, and historically disenfranchising registration procedures. One commentator has noted that "[ $t$ ]he more representative [government] is of the concerns of its electors, the greater its vitality and the better the long-run prognosis for its continued health." 212 Judicial intervention in the realm of voter registration will help to guarantee that the United States will fulfill this mandate into the twenty-first century.

208 See, e.g., Crotty, supra note 11, at 102-06 (reviewing such registration reform proposals).

210 See sources cited supra note 177.

211 P. Kimball, supra note 18 , at 290.

212 Crotty, supra note 11 , at 89. 
